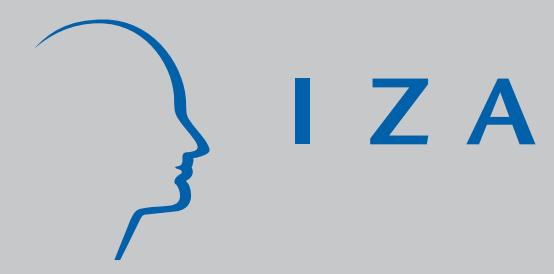

IZA DP No. 2133

Technical Change and Total Factor Productivity Growth for Chinese Provinces: A Panel Data Analysis

Alice Shiu

Almas Heshmati

May 2006 


\title{
Technical Change and Total Factor Productivity Growth for Chinese Provinces: A Panel Data Analysis
}

\author{
Alice Shiu \\ Hong Kong Polytechnic University \\ Almas Heshmati \\ TEPP, Seoul National University, \\ RATIO Institute and IZA Bonn
}
Discussion Paper No. 2133
May 2006

\author{
IZA \\ P.O. Box 7240 \\ 53072 Bonn \\ Germany \\ Phone: $+49-228-3894-0$ \\ Fax: +49-228-3894-180 \\ Email: iza@iza.org
}

\begin{abstract}
Any opinions expressed here are those of the author(s) and not those of the institute. Research disseminated by IZA may include views on policy, but the institute itself takes no institutional policy positions.

The Institute for the Study of Labor (IZA) in Bonn is a local and virtual international research center and a place of communication between science, politics and business. IZA is an independent nonprofit company supported by Deutsche Post World Net. The center is associated with the University of Bonn and offers a stimulating research environment through its research networks, research support, and visitors and doctoral programs. IZA engages in (i) original and internationally competitive research in all fields of labor economics, (ii) development of policy concepts, and (iii) dissemination of research results and concepts to the interested public.
\end{abstract}

IZA Discussion Papers often represent preliminary work and are circulated to encourage discussion. Citation of such a paper should account for its provisional character. A revised version may be available directly from the author. 


\title{
Technical Change and Total Factor Productivity Growth for Chinese Provinces: A Panel Data Analysis
}

\begin{abstract}
We present in this paper the panel econometrics estimation approach of measuring the technical change and total factor productivity (TFP) growth of 30 Chinese provinces during the period of 1993 to 2003 . The random effects model with heteroscedastic variances has been used for the estimation of the translog production functions. Two alternative formulations of technical change measured by the single time trend and the general index approach are used. Based on the measures of technical change, estimates of TFP growth could be obtained and its determinants were examined using regression analysis. The parametric TFP growth measure is compared with the non-parametric Solow residual. TFP has recorded positive growth for all provinces during the sample period. Regional breakdown shows that the eastern and central regions have higher average TFP growth when compared with the western region. Foreign direct investment (FDI) and information and communication technology (ICT) investment are found to be significant factors contributing to the TFP difference. While these two factors are found to have significant influence on TFP, their influence on production is relatively small compared to traditional inputs of production.
\end{abstract}

JEL Classification: $\quad$ C23, D24, E22, O18, O47

Keywords: technical change, TFP growth, provinces, China, ICT, FDI, infrastructure

Corresponding author:

Almas Heshmati

Techno-Economics \& Policy Program

College of Engineering

Seoul National University, Bldg \# 37

San 56-1, Shinlim-dong, Kwanak-gu

Seoul 151-742

South Korea

Email: heshmati@snu.ac.kr

\footnotetext{
* The authors would like to thank Dr. Vincent Mok at the Hong Kong Polytechnic University and Professor Ira Horowitz at the University of Florida for providing valuable comments on an earlier version of this paper which have greatly improved the structure, content and analysis of this paper. Thanks are also due to Wanshan Yang for providing and compiling parts of the provincial level data used in this study.
} 


\section{Introduction}

The growth of economics is to a large extent the result from technical change. This was evidenced by Solow (1957)'s seminal paper, ${ }^{1}$ in which technical change was found to be the main source of economic growth in the United States during the $20^{\text {th }}$ century. Solow treated the rate of technical change as the "residual" which measures not only technological change but also the ignorance of both measurable and non-measurable factors with expected positive effects on production. As a result, it is very likely that the Solow residual would overestimate the rate of technical change. However, with specification of a production function that accounts for inputs other than capital and labor, and production environmental factors, the bias in the measurement of the true rate of technical change could be reduced.

In econometrics estimation of production functions, technical change can be estimated using the single time trend (TT) approach (i.e. inclusion of a deterministic time trend in the estimation of a production function) (Solow, 1957; Tinbergen, 1942; Christensen et al, 1973) or alternatively by the general index (GI) approach (Baltagi and Griffin, 1988). ${ }^{2}$ With the TT approach, the trend may be linear or non-linear, and certain specifications such as flexible functional forms may allow interactions between time and other explanatory variables. This allows the rate of technical change to be non-constant and non-neutral (Gollop and Jorgenson, 1980, Jorgenson and Fraumenti, 1981, Gollop and Roberts, 1983). The derivative of the production function with respect to time provides measure of the rate of technical change.

A critical weakness of the TT approach is the smooth pattern of growth with indefinite progress or regress rates. In order to capture the year-to-year changes in technical change, the GI approach could be used instead. It uses a set of time-specific dummies and their interactions with other explanatory variables to estimate a general index of the technical change.

With the estimates of input elasticities and rate of technical change, total factor productivity (TFP) can be calculated accordingly using both TT and GI approaches. In this

1 Solow (1957) and Tinbergen (1942) were the first researchers to explicitly discuss the use of a production function for modeling and measuring productivity growth.

2 An intermediate approach is multiple time trend approach where multiplicity of trends are introduced to capture structural changes such as pre- and post-economic reform periods (see Heshmati and Nafar, 1998). The data in the current study cover only the post Chinese reform period. 
paper, TFP is calculated to include two parts, i.e. the rate of technical change and deviation from constant returns to scale. ${ }^{3}$

The present paper attempts to estimate the rate of technical change and TFP growth parametrically using both TT and GI representations of technical change in the panel data models. The empirical focus has been placed on measuring the rate of technical change and TFP growth for 30 Chinese provinces during the rapidly growth period of 1993 to 2003. By considering the translog specification of the production function (Christensen et al., 1973), flexible (province- and time-specific) technical change, returns to scale and input elasticities were estimated. With the estimates of technical change and the scale effect, TFP growth at each data point can be computed. TFP determinants can be further identified and their impacts could be quantified using regression analysis.

The analyses in the paper improve our understanding of the growth rate of provincial technical change and TFP in China and enhance our knowledge on recent regional development. Information on differences in regional productivity growth is important for government to formulate policies of allocation and redistribution of productive resources in reducing the growing regional inequality in China.

The following section provides an overview of the literature on using aggregate production function models to measure China's economic growth. Section 3 explains the data used to conduct the empirical analysis and sections 4 and 5 describe the theoretical model and estimation procedures to estimate the aggregate production function at the provincial level. Section 6 describes the empirical result of the production function and section 7 provides the summary and conclusion.

\section{Literature Review}

China has achieved high economic growth since the adoption of the open-door policy in 1978. This is evidenced by the high average growth rate of real GDP per annum $(9.37 \%)$ over the past twenty-five years (Holz, 2005). This remarkable economic growth has led to a heated debate on whether the main driving force is productivity growth or factor

\footnotetext{
${ }^{3}$ If one assumes constant returns to scale, then technical change is equal to TFP growth.
} 
accumulation. A number of existing studies have found that the high economic growth in China was brought about mainly by capital accumulation, e.g. Chow (1993), Yusuf (1994), Borensztein and Ostry (1996), Hu and Khan (1997), Sachs and Woo (1997), Ezaki and Sun (1999), Woo (1998), Wu (2004) and Arayama and Miyoshi (2004). However, according to Krugman (1994), massive accumulation of inputs will soon limit China's growth if there is little improvement in productivity. Indeed, the stress of promoting productivity growth in the 90s had led to the bloom of analyses of productivity and sources of growth over the past decade.

Other than the analysis of sources of growth of TFP, a number of previous productivity studies on China's economy examined productivity of different ownership types (e.g. Chen et al. (1998), Jefferson (1990), Dollar (1992), Jefferson and Xu (1994), Xu and Wang (1999), Hu (2001) and Zheng et al. (2003)). Other categories of productivity research include the examination of sectoral productivity growth (e.g. Lin (1992), Jefferson, Rawski and Zheng (1992, 1996), Wu (1995), Wu (2000), Xu (1999) and Zheng and Zheng (2001).) and the investigation of productivity difference among regions (e.g. Demurger (2001), Lee (2000), Song et al.(2000), Cai et al. (2001), Bao et al. (2002) and Demurger et al (2002)).

Our paper contributes to the branch of research which focuses on the investigation of sources of economic growth. In particular, we incorporate ICT investment in addition to traditional inputs in our production function. Although China has a rapid growing ICT sector over the past decade, there is a lack of empirical research that examines the contributions of ICT investment to the Chinese economic growth. Meng and Li (2002) provided some evidence on China's ICT industrial development and diffusion in recent years, while Heshmati and Yang (2005) investigated the relationship between TFP growth and ICT investment at the aggregate national level and provide estimation of the returns to ICT investment.

Besides looking at the rate of technical change and TFP growth at the national level, we also consider these measures at both provincial and regional levels, which enables us to have a more thorough understanding of the regional diversity of growth patterns in China.

Regarding the methodology used in the productivity research, a handful of studies on 
productivity of China have applied the growth accounting approach, ${ }^{4}$ e.g. Chow (1993), Borensztein and Ostry (1996), World Bank (1996), Hu and Khan (1997), Maddison (1998), Woo (1998), Demureger (2000), Ezaki and Sun (1999), Wang and Yao (2003) and, Arayama and Miyoshi (2004). Some of these studies used Cobb-Douglas average production function, such as Chow (1993), Ezaki and Sun (1999) and Wang and Yao (2003), while others like Hu and Khan (1997) and Arayama and Miyoshi (2004) applied the translog production function. These studies focus on the estimation of factor input shares to be used in the computation of the aggregate productivity growth over time. Nevertheless, all of these studies have found positive TFP growth in the post-reform China.

There are other studies which used the frontier production approach to measure TFP growth in China, such as Chen (2001) and Zheng and Hu (2004), which applied the Malmqist indexes of TFP growth. ${ }^{5}$ The TFP growth can be decomposed into two components, namely efficiency change and technological change. Chen (2001) found positive average TFP growth during the recent period of 1992 to 1999, and technology improvement was found to be a larger component for TFP growth. Zheng and $\mathrm{Hu}$ (2004) found considerable average productivity growth for most of the data periods during 1979-2001, which was accomplished through technical progress instead of efficiency improvement. Wu (1999), on the other hand has applied the stochastic frontier approach on Chinese provinces to examine the productivity growth in China's reforming economy and found positive TFP growth in China during the post-reform period of 1982 to 1995.

In this paper, instead of using the growth accounting and frontier production approaches, we apply the panel data econometrics approach for estimation of the production function. The growth accounting approach which focuses on limited number of inputs and the strong assumption of constant returns to scale, and fixed income share over long period of time tends to produce biased and overestimated measure of growth. As far as the authors concern, this paper is the first to apply the panel data models for parametric estimation of the rate of technical change in China. By using the panel data model, we could control for unobservable time invariant provincial effects. Besides, our specification of the flexible

\footnotetext{
${ }^{4}$ The growth accounting approach involves the subtracting of the growth of factor accumulation at a constant rate from the output growth to obtain the TFP measure. In this case, TFP is equivalent to technical change.

${ }^{5}$ The Malmquist TFP index measures the TFP change between two data points by calculating the ratio of the distances of each data point relative to a common technology.
} 
functional form for the production function is enriched by the introduction of non-traditional factor inputs such as ICT investment and inflow of FDI.

\section{The Provincial-Level Data}

In this paper, we use a combination of the latest published and non-published provincial data of China, which provide update information of the development of the rate of technical change and TFP growth in China.

Our data for estimation of the translog production function in the first stage comprises the following output and input variables for 30 provinces during the period 1993 to 2003. Output is measured as aggregate gross domestic product (GDP) (in 100 million yuan). The vector of inputs include information and communication technology (ICT) investment (in 100 million yuan), capital stock (CAP) (in 100 million yuan), foreign direct investment (FDI) inflow (in \$US10,000), and number of persons employed at year-end (in 10,000 persons).

Other than the variables considered in the first stage of estimation, additional variables are used as determinants of TFP growth. These include: regional and time period dummy variables, road infrastructure (ROAD) (total length of highways in km), government consumption (GOV) (in 100 million yuan), total investment (INV) (in 100 million yuan), household telephone subscribers (TEL) (in number of subscribers), openness (OPEN) (the ratio of import plus export to GDP), reform (REFORM) (the ratio of state-owned enterprises industrial value to total gross industrial value) and percentage of highly educated labor (PCNT) (the ratio of number of graduates of regular institutions of higher education to population).

The data is mainly taken from various issues of Chinese Statistical Yearbooks and the official Chinese government website. The ICT investment data used in the paper is supplied by the statistical department of Ministry of Information Industry (MII). ${ }^{6}$

\footnotetext{
${ }^{6}$ The ICT investment includes investments in the production of radios, televisions, fixed telephones, mobile telephones, personal computers and communication equipments. The share of ICT investment to total investment was around $1 \%$ during the early 80 s, but it has increased to approximately $5 \%$ in the late 90 s and after 2000.
} 
The dummy variables capture unobservable time-invariant province effects (such as skills, planning and management differences at the provinces and location advantages/disadvantages) and province-invariant time effects (such as central or local economic policy effects). These have been considered as the determinants of TFP growth in the regression analysis in the second stage. As the monetary input variables are expressed in nominal prices, they are deflated using the provincial GDP deflators. ${ }^{7}$ The physical capital stock data from 1993-2003 is taken from Wu (2004) and the authors extend the series to include 2003 data using the backcasting method. ${ }^{8}$ The GDP is also deflated using GDP deflator which varies across provinces and time.

In addition to the variables considered above, the single time trend (TRN) is used to represent the exogenous rate of technical change in the TT model and time specific dummies (TD) are used to represent the rate of technical change in the GI model. The total number of observations is $11 \times 30=330$. Table 1 shows the summary statistics of the deflated variables used in the paper. Average GDP, as well as inflow of FDI and telephone lines.

\section{[Insert Table 1 here]}

\section{The Production Model}

In this study, we specify the average production function ${ }^{9}$ in logarithmic form as follows:

$$
\ln Y_{i t}=\beta_{0}+\sum_{j=1}^{J} \beta_{j} \ln X_{j i t}+\varepsilon_{i t}
$$

where $\ln Y_{i t}$ is the logarithm of output measure of total GDP of province $\mathrm{i}(\mathrm{i}=1,2, \ldots, \mathrm{N})$ in period $\mathrm{t}(\mathrm{t}=1,1, \ldots, \mathrm{T})$ and $\ln X_{i t}$ is a vector of logarithm of $\mathrm{J}(\mathrm{j}=1, \ldots, \mathrm{J})$ inputs. The inputs include labor (LAB), capital stock (CAP), foreign direct investment (FDI), and information and communication technology (ICT) investment. $\beta$ is a vector of unknown parameters (input

\footnotetext{
7 The authors derived the nominal and real GDP indexes based on data from various Chinese Statistical Yearbooks and calculated the GDP deflators accordingly. There were smooth increasing trends of the calculated GDP deflators and no abnormalities were found. The data and associated graphs could be provided upon request.

${ }^{8}$ The capital stock is calculated using the backcasting approach (see Chapter 2 of Wu (2004)) and it is provided by Dr. Yanrui Wu. It is calculated based on the assumption that the rate of depreciation is $4 \%$. The series is expressed in 1952 constant prices.

9 The production function is assumed to maximize output with given inputs and technology available to provinces. It has the properties of positivity in inputs, nonemptiness of output, symmetry, monotonicity and convexity. In addition, it is continuous at any point and twice-continuously differentiable.
} 
elasticities) to be estimated.

The error term follows a two way error component structure consisting of an unobserved province-specific effect $\left(v_{i}\right)$, a time-specific effect $\left(\lambda_{t}\right)$ and a random error term $\left(u_{i t}\right)$ :

$$
\varepsilon_{i t}=v_{i}+\lambda_{t}+u_{i t}
$$

The province-specific effect is assumed to be either fixed (accounted for in separate intercept term) or random with mean zero and heteroscedastic variance, $\sigma_{v_{i}}^{2}$. The timespecific effect is assumed to be fixed. Finally, the random error term is assumed to be random and have mean 0 and constant variance, $\sigma_{u}^{2}$.

The model in equation (1) is estimated with the specification of a translog functional form, by which the technology is represented in two ways by: (i) a time trend and (ii) vector of time specific dummies. The former is called the Single Time Trend (TT) model whereas the latter is called the General Index (GI) model. Equations (3) and (4) show the specifications of the TT and GI models in their respective translog form:

$$
\begin{aligned}
\ln Y_{i t}= & \beta_{0}+\sum_{j=1}^{J} \beta_{j} \ln X_{j}+\beta_{T} T_{t}+\beta_{T T} T_{t}^{2} \\
& +\sum_{j} \sum_{k} \beta_{j k} \ln X_{j i t} \ln X_{k i t}+\sum_{j} \beta_{j T} \ln X_{j i t} T_{t}+v_{i}+\mu_{i t} \\
\ln Y_{i t}= & \beta_{0}+\sum_{j=1}^{J} \beta_{j} \ln X_{j}+\lambda_{t} \\
& +\sum_{j} \sum_{k} \beta_{j k} \ln X_{j i t} \ln X_{k i t}+\sum_{j} \beta_{j T} \ln X_{j i t} T_{t}+v_{i}+\mu_{i t}
\end{aligned}
$$

where $v_{i}$ and $\lambda_{t}$ are N-1 and T-1 vectors of provinces and time dummy variables. It should be noted that in the GI model, i.e. equation (4) there is no squared time effects, and for the interaction of time and inputs we have used a time trend to reduce the number of parameters to be estimated. ${ }^{10}$

Based on equations (3) and (4), the input elasticities (E) and the rate of technical change (TC) in the TT and GI models can be calculated as follows:

$$
E_{j i t}=\partial \ln Y_{i t} / \partial \ln X_{j i t}=\beta_{j}+\beta_{j j} \ln X_{j i t}+\sum_{k} \beta_{j k} \ln K_{k i t}+\beta_{j T} T_{t}
$$

\footnotetext{
${ }^{10}$ See Kumbhakar et al. (1999) for more information on using a time trend for the interaction terms instead of using vector of time dummies.
} 


$$
\begin{aligned}
& T C_{i t}^{T T}=\partial \ln Y_{i t} / \partial T_{t}=\beta_{T}+\beta_{T T} T_{t}+\sum_{j} \beta_{j T} \ln K_{j i t}, \text { and } \\
& T C_{i t}^{G I}=\partial \ln Y_{i t} / \partial T_{t}=\left(\lambda_{t}-\lambda_{t-1}\right)+\sum_{j} \beta_{j T} \ln K_{j i t} .
\end{aligned}
$$

The rate of technical change can further be decomposed into the pure component $\left(\left(\beta_{T}+\beta_{T T} T_{t}\right)\right.$ and $\left.\left(\lambda_{t}-\lambda_{t-1}\right)\right)$ and the non-neutral $\left(\sum_{j} \beta_{j T} \ln K_{j i t}\right)$ components. Pure technical change refers to neutral shift of the production function (or it implies that all inputs are affected equi-proportionately by technical change) while non-neutral technical change means biased technical change. Technical change is biased if the marginal rate of substitution (MRS) between any two inputs (measured along a ray through the origin) is affected by technical change. It implies that technical change will tend to influence the relative contribution of each input to the production process.

If the sum of the input elasticities calculated in equation 5 is calculated, returns to scale (RTS) can be obtained as follows:

$$
R T S_{i t}=\sum_{j} E_{j i t},
$$

where $E_{j i t}$ is the elasticity of output for province $\mathrm{i}$ with respect to input $\mathrm{j}$ at period t. It measures the percentage change of output in response to a $1 \%$ increase in respective input. RTS is greater than, equal to or smaller than 1, indicating technology is exhibiting increasing, constant or decreasing RTS, respectively. All input elasticities, returns to scale and rate of technical change are computed at every point of the data and vary across provinces and over time. ${ }^{11}$ By using equations (5) to (8), the parametric TFP growth based on the translog production function for both TT and GI models can be obtained as follow:

$$
T F \dot{P}_{i t}^{T T}=T C_{i t}^{T T}+\left(R T S_{i t}^{T T}-1\right) \sum_{j} E_{j i t}^{T T} \dot{X}_{j i t} \text { and }
$$

$$
T F \dot{P}_{i t}^{G I}=T C_{i t}^{G I}+\left(R T S_{i t}^{G I}-1\right) \sum_{j} E_{j i t}^{G I} \dot{X}_{j i t} .
$$

The objective here is not only to estimate TFP growth but also to identify the determinants of growth and to quantify their impacts. After obtaining the value of TFP growth, the following regressions are estimated to examine the effects of possible factors

\footnotetext{
11 Introduction of such high degree of flexibility often leads to some point input elasticities violating the regulatory conditions (i.e. having negative signs). The common practice is to replace them with either zero or missing values. In this study, the number of point elasticities violating the regulatory conditions is small and as such do not change the signs of the mean elasticities by province and over time.
} 
leading to TFP growth. ${ }^{12}$ Again we control for unobserved time and province heterogeneity and identify several determinant factors. The relationship between these factors and TFP growth is estimated using a fixed-effect approach:

(11) $T F \dot{P}_{i t}=\beta_{0}+\beta_{i c t} I C T+\beta_{f d i} F D I+\beta_{i n v} I N V+\ldots \ldots .+\beta_{\text {open }} O P E N+\sum_{i=1}^{30} B_{i} D_{i}+\sum_{i=2}^{10} T_{i}+e_{i t}$

where the determinant variables ICT, FDI, INV, ROAD, TEL, GOV, PCNT, REFORM and OPEN are previously defined and $\mathrm{D}$ and $\mathrm{T}$ are vectors of unobservable fixed province- and time- specific effects.

\section{Estimation}

In order to estimate the above production function, we use the random-effects model with a two way error components structure, a province-specific term $\left(v_{i}\right)$, a time-specific term $\left(\lambda_{t}\right)$ and a combined random error term $\left(u_{i t}\right)$. The time-specific effects are replaced by a time trend or a vector of time specific dummies to represent exogenous rate of technical change. By adding the time effects to the deterministic part of the production function, the model in vector form reduces to a one way error component structure:

$$
\begin{aligned}
& y_{i t}=\mathbf{x}_{i t}^{\prime} \beta+\varepsilon_{i t}, \\
& \varepsilon_{i t}=v_{i}+u_{i t},
\end{aligned}
$$

where lower case of dependent variable $y$ and vector of independent variables $x$ indicate logarithmic transformation of those variables. The $v_{i}$ are assumed to be identically and independently distributed (i.i.d.) normal with mean 0 and heteroscedastic variance $\sigma_{v_{i}}^{2}$, the random error term is assumed to be i.i.d. normal with mean 0 and constant variance, $\sigma_{u}^{2}$, and the two error terms are assumed to be uncorrelated among themselves and with the $\mathrm{x}$ variables, i.e. $E\left(v_{i} \mid x_{i t}\right)=E\left(u_{i t} \mid x_{i t}\right)=0$. Our combined fixed- and random-effects model implicitly assumes that provinces not only response to policy changes heterogeneously, but they also develop heterogeneously over time.

Statistical tests have been applied to test for the presence of autocorrelation and heterocedasticity. Results of regressing the ordinary least squares (OLS) residuals on their lagged terms obtained from the estimation of the pooled model show that there is no sign for

\footnotetext{
${ }^{12}$ Two regressions have been estimated. One uses TFP growth estimated by the TT model whereas the other uses TFP growth estimated by the GI model.
} 
autocorrelation, but there is the presence of heterocedasticity. To deal with the problem, we apply the following transformations to both TT and GI models to correct for heterocedasticity:

$$
y_{i t}^{*}=\mathbf{z}_{i t}^{*} B+\varepsilon_{i t}^{*},
$$

The transformed variables are defined as follow:

$$
\begin{aligned}
& y_{i t}^{*}=y_{i t}-\alpha_{i}\left(1 / T \sum_{t} y_{i t}\right), \\
& \mathbf{z}_{j i t}^{*}=\mathbf{z}_{j i t}-\alpha\left(1 / T \sum_{t} z_{j i t}\right), \text { for each explanatory variable } \mathrm{j} \\
& \varepsilon_{i t}^{*}=\varepsilon_{i t}-\alpha_{i}\left(1 / T \sum_{t} \varepsilon_{i t}\right), \text { and } \\
& \alpha_{i}=1-\sigma_{u} / \sqrt{\left(T \sigma_{v i}^{2}+\sigma_{u}^{2}\right)}
\end{aligned}
$$

where $\alpha_{i}$ is the heteroscedasticity transformation parameter and the random error variance $\sigma_{u}^{2}$ is estimated as the mean square error of the residuals $\left(\hat{u}_{i t}\right)$ of the translog production function by least squares dummy variables method. The variance $\sigma_{v_{i}}^{2}$ could be derived using $\sigma_{v_{i}}^{2}=\gamma_{i}^{2}-\sigma_{u}^{2}$, where $\gamma_{i}^{2}$ is the total variance calculated as $\sum_{t} e_{i t}^{2} /(T-k)$ based on the pooled OLS residuals (e). After having transformed the dependent and independent variables, OLS method is applied on the transformed variables to yield more efficient estimates which are equivalent to estimates generated by Feasible Generalized Least Squares (FGLS) method.

\section{Empirical Results}

\section{Specification Tests and Parameter Estimates}

The translog production models ${ }^{13}$ of equations (3) and (4) have been estimated, where the dependent variable is the log of gross domestic product (GDP) and the independent input variables include the log of labor (LAB), capital stock (CAP), foreign direct investment (FDI), and information and communication technology (ICT) investment. Equation 14 has been used to transform the dependent and independent variables and OLS method has been applied on the transformed variables to yield feasible GLS estimates.

Table 2 shows the GLS heteroscedastic translog parameter estimates of the TT and GI models, respectively. Both models have adjusted R-square of 0.9994 and 0.9995, respectively. Results of the two models are similar, and labor, and capital stock are significant at $1 \%$ level,

\footnotetext{
${ }^{13}$ F-test based on residual sum of squares rejects the simpler (Cobb-Douglas with only first order terms and generalized Cobb-Douglas with both first order and second order terms) functional forms in favour of the translog form.
} 
indicating that factor accumulation has significant contribution to economic growth. The first order time trend (TRN) coefficient in the TT model is significant at $1 \%$ level, and most of the dummies in the GI model are significant at 5\% level. Since the coefficients of the translog production functions are not directly interpretable, we will focus on the derived results from the parameter estimates such as elasticities of inputs, RTS, rate of technical change and TFP growth rates.

[Insert Table 2 here]

\section{Variance Components}

The panel models that we have considered in the paper allow us to investigate the province-specific heterogeneity in development. The transformation parameter $\left(\alpha_{i}\right)$ shows the extent of heterogeneity of provinces. Its size ranges between zero (pooled OLS) and one (within estimation method). The size of $\alpha_{i}$ is determined by the length of the sample period, the province-specific $\left(\sigma_{v_{i}}^{2}\right)$ and random noise variance $\left(\sigma_{u}^{2}\right)$ components. The former variance varies across provinces while the latter is kept constant. Results of variances for each province are shown in Table 3. Note that these variance components are assumed to be constant over time.

\section{[Insert Table 3 here]}

For the purpose of comparison, interpretation of the results is also presented in light of the regional economies. ${ }^{14}$ The western region is having the highest average of $\alpha_{i}$ among the three regions over time, indicating the largest variation of production of provinces over time as well as largest gap in development relative to the other regions. This could possibly be the result of differences in access and effective utilization of actually utilized foreign capital, physical capital and other infrastructure inputs on production during the 90 s (see $\mathrm{Ng}$ and Leung (2002)). The variance of the random noise component $\left(\sigma_{u}^{2}\right)$ is extremely small and constant at 0.0039 over time and across provinces.

\footnotetext{
${ }^{14}$ The Eastern region contains 12 provinces (Beijing, Tianjin, Hebei, Liaoning, Shanghai, Shandong, Zhejiang, Jiangsu, Fujian, Hainan, Guangdong, and Guangxi), whereas the Central region contains nine provinces neighboring the eastern provinces (Shanxi, Inner Mongolia, Jilin, Heilongjiang, Anhui, Jiangxi, Henan, Hunan and Hubei) and the Western region covers nine provinces in the Western region (Sichuan, Yunnan, Guizhou, Shaanxi, Gansu, Tibet, Qinghai, Ningxia and Xinjiang).
} 
The eastern region is found to have the smallest average province-specific variance $\left(\sigma_{v_{i}}^{2}\right)$, indicating small deviation from the average trend. This could be supported by the fact that when a region is experiencing more advanced development, any increase in foreign investment or investment in fixed assets will change the production to a smaller extent than in a region of less advanced development.

\section{Input Elasticities and RTS}

Estimates of input elasticities (the percentage change of output in response to a $1 \%$ increase in respective input), RTS and the rate of technical change can be obtained by applying equations (5) to (8). ${ }^{15}$ These measures are both province- and time-specific. Tables $5 \mathrm{~A}$ and $5 \mathrm{~B}$ show the mean values by year and provinces for the TT and GI models, respectively. Results of both models (with the exception of the rate of technical change) are similar as expected.

\section{[Insert Tables 5A and 5B here]}

Results in Tables 5A and 5B show that elasticities of labor and capital stock have the largest magnitudes among others, indicating a larger responsiveness of GDP to changes in labor and capital stock. This indicates that both capital stock and labor have influential effect on economic growth, confirming the fact that factor accumulation has played an important role in contributing to the remarkable Chinese economic growth. The elasticities of FDI and ICT investment are much smaller in magnitude though. The two models have different results regarding elasticity for ICT investment. For the TT model, elasticity for ICT investment was decreasing over time and it changed to a negative sign since 1998. For the GI model, it was generally increasing till 2001 and then declined. Although the magnitudes of elasticities are smaller comparing to capital stock and labor, evidence shows that both FDI and ICT investment increased generally in the 1990s and have become important factors promoting economic growth.

In particular, the rate of FDI utilization (share of actual FDI in total contractual FDI) has increased steadily from 1979 till late 90s, which is reflected by the trend of investment venturing beyond traditional manufacturing industries into the information technology, high-

\footnotetext{
${ }^{15}$ Figures 1 to 3 show the estimates of input elasticities and RTS over the sample period for the TT and GI models.
} 
tech, and service sectors. Possible explanation for our results of small elasticity of FDI could be the presence of ambiguity, complexity and inflexibility of policies, which impose higher transaction costs on foreign-funded enterprises and thereby limiting the effect on GDP. Besides, the lack of coordination among various bureaucratic units further hampers arbitration between government bureaus and foreign investors.

The eastern region is found to have the largest average elasticity of FDI among the three regions in both models, implying that utilization and contribution of FDI is higher in the eastern region. It is believed that with better infrastructure and spatial and topographical advantages, the eastern region can enjoy lower cost of production and increase the return on investment which in turn attracts more FDI and thereby further facilitating economic growth. See Bao et al. (2002). Demurger (2000) also found that FDI was an effective channel for technology transfer that mainly benefited the eastern provinces.

For the western region, average elasticity of capital is found to be largest among the three regions, indicating the importance of increasing capital to boost development in the region. This also provides evidence that the launch of the Western Region Development has generated good effects on the economy. Average elasticity of FDI for the western region is found to be much smaller than other regions due to insufficient infrastructure, low concentration of skilled labor and inconvenient transportation, which in turn increases the production cost and thereby reducing return to investment and economic growth.

Results from both TT and GI models indicate that elasticity of FDI was negative for three western provinces, i.e. Qinghai, Ningxia and Xinjiang, indicating that an increase in FDI will lead to a decline in economic growth. This result could be supported by Hanson (2001), Gorg and Greewood (2002) and Alfaro (2003), which suggested that the evidence of FDI generating positive spillovers into host country is weak and sometimes negative. Reallocation of resources following inflow of FDI might be initially in productivity terms less effective. See also Yeung and Mok (2002) for more support of this result. Regarding average elasticity of labor, it was found to be largest in the central region, indicating that the central region is catching up with the eastern region in terms of utilization of labor to generate growth. 
Our results of small ICT investment impact on production is consistent with studies which conclude that for developing countries, returns from non-information technology (IT) capital investments are substantial while those from IT capital investment are not statistically significant. Dewan and Kraemer (2000) argued that the overall lack of IT enhancing complementary factors in developing countries could be the reason for the result. They also indicated that developing countries need to accumulate certain level of experience with information technologies before investments in IT could provide better returns to production. See Figures 1 and 2 for development of input elasticities over time by TT and GI models.

RTS is a measure of the changes in the level of output to proportional changes in inputs. Results in Tables 5A and 5B indicate that during the sample period, RTS is greater than 1 (mean 1.069 for TT model and 1.094 for GI model), i.e. increasing RTS in both models. The highest average RTS is found in the western (Tibet) region for both models. This result may imply that when there are changes in inputs in Tibet, the relative effect on increase in output will be larger than that in a more developed region. Tibet deserves particular attention despite it is an inland province. It has a relatively large proportion of its foreign trade handled by foreign funded companies and these were dominated by Nepalese and Pakistani traders involved in cross-border trade. See Gipouloux (1998). The spillover and learning effects generated by trade, together with the "advantages of backwardness" ${ }^{\text {16 }}$ may help to explain the high average RTS enjoyed by Tibet.

It is interesting to note that both Shanghai and Guangdong have experienced decreasing RTS. While increasing RTS was found for these provinces in the GI model, the magnitudes were relatively smallest among all provinces. These results for Shanghai and Guangdong could be explained by the fact that when a province is more advanced in development and production is close to the optimal level, any increase in input would change the production to a smaller extent.

\section{Technical Change}

Technical change is the time derivative of output. It measures the percentage change in output due to a unit elapse of time. Using the estimated elasticities, technical change is

\footnotetext{
${ }^{16}$ The "advantages of backwardness" indicates that backwardness may carry an opportunity for modernization in disembodied and embodied technology. Regions which are behind in development may have the potential to leap forward. See Abramovitz (1986).
} 
calculated according to equations 6 and 7, respectively for TT and GI models. Possible factors which lead to difference in technical change among individual provinces include the historical levels of investment in physical capital and infrastructure for development, the geographical location of resources and concentration of skills and production potential across provinces. $^{17}$

Referring to Tables $5 \mathrm{~A}$ and $5 \mathrm{~B}$, for the TT model, the overall mean of technical change is $8.5 \%$ whereas in the GI model, the mean is $8.65 \%$, indicating that Chinese provinces have been experiencing technical progress. For the TT model, the rate declines over time switching from progress to regress in 2003. For the GI model, the rate generally declines over the sample period, except in 2000 and 2002.

The rate of technical change has been decomposed into the effects due to both pure technical change and non-neutral technical change as shown in equations 6 and 7. The average pure component for provinces is found to be decreasing over time for the TT model, whereas it generally declined and increased in 2000 and 2002. The figure became negative in 1999. The main difference between the TT and the GI models is that the non-neutral technical change is negative in magnitude in the TT model and it declined until 2001, whereas for the GI model, the non-neutral technical change is positive in magnitude and is generally decreasing.

For the interaction between technology and the inputs, we have used a time trend in both cases. We would expect similar non-neutral component. The main source of difference between the results from the two models with respect to the rate of technical change should be in the patterns of the neutral component and the way it affects the input utilization and production conditions.

Regarding the regional aspect, the pure component is constant while the non-neutral component varies across provinces due to variability of inputs. For the TT model, eastern region records the largest negative non-neutral technical change as a result of input saving technology development. Among the three regions, the central region is found to have the

\footnotetext{
${ }^{17}$ Figure 4 shows the trend of technical change over the sample period for both TT and GI models.
} 
largest positive magnitude of the non-neutral component in the GI model. This indicates that effect of technical change on marginal substitution of inputs is higher in the central region.

\section{Total Factor Productivity}

After examination of the technical change, we continued to look at the TFP growth estimated by equations (9) and (10). The sample mean percentage growth rate is found to be $8.86(0.78)$ and $9.22(0.70)$ with small dispersion (in parenthesis) in the TT and GI models respectively.

Our results reported in Tables 5A and 5B show that TFP growth was positive in the 1993-2003 period. The growth of TFP in each province in the 90s is closely related to the expansion of non-state enterprises, the increase in FDI and to a lesser extent, the degree of human development. Besides, but it depends heavily on region specific growth enhancing elements (Ezaki and Sun (1999)).

There is a general trend for TFP growth to decline in the TT model. For the GI model, TFP growth records an increase in 1994, 2000 and 2002-2003 though. All three regions are found to have positive TFP growth during the sample period in both models. The magnitude is somewhat larger in the GI model though. The central region and western region are found to have largest and smallest average TFP growth, respectively in both models. Although there were increased public budgets for infrastructure investment in the western region and the establishment of a Western Region Development office under State Council to formulate development strategies and coordinate the implementation, more is needed to be done. Our results confirm the fact that the socio-economic and topographic features of the western region imply higher transportation costs and a greater requirement for human capital as well as physical infrastructure construction. See Wu (1999) for a comparison of productivity and efficiency performance among the three regions.

For the purpose of sensitivity analysis of the results and comparison with the mainstream literature, we have computed the Solow residual (growth accounting)-based growth rates. The corresponding TFP growth measures are reported in Table 4A and Table 4B. The sample mean of TFP growth is $9.19 \%$ and $8.70 \%$ respectively. As expected, the dispersion in the TT specification (2.83\%) is larger compared to the GI specification $(2.11 \%)$. 
The TT model as a result of its restrictive functional form shows a lower year to year variation among the adjacent periods, but larger deviation at the beginning and end of the period in relation to the sample mean. The TT and GI sample mean values of TFP might be quite close, but the distributions are different. The growth accounting TFP growth rates patterns are similar to those of parametric approach concerning regional concentration and dispersion. However, they differ somewhat in level by provinces as a result of differences in returns to scale, factor substitution effects and systematic provincial heterogeneity effects.

\section{Determinants of TFP Growth}

To investigate the possible determinants of variations in TFP growth, equation 11 is estimated. Results are shown in Table 5. The adjusted R-square for the regression in the case of the TFP growth estimated by the TT model is 0.9893. ICT investment and FDI have very significant impact on the TFP growth. The former has negative impact while the latter has positive impact. The time specific dummies have relatively large and significant impact on the TFP growth. For the GI model, the adjusted R-square is 0.9917. Similarly, ICT investment and FDI and the time specific dummies are found to have significant impact on TFP growth.

[Insert Table 5 here]

Our results in both models show that FDI is a significant factor contributing to TFP growth. The contribution of FDI to productivity has been widely studied in the literature and there is a general consensus on the positive impacts of FDI on economic development (see Borensztein et al. (1998), OECD (1998), Blomstrom et al. (1994), Markusen and Venables (1999), Xu (2000) and Soto (2000)). It is generally believed that FDI contributes to TFP growth through the provision of better access to technologies for the local economy and spillover. Foreign firms may increase the degree of competition in host-country markets which motivate inefficient firms to invest more in physical or human capital. Besides, foreign firms may provide training of labor and management which would improve productivity. In particular, the high TFP growth in early years of the sample period could be explained by the large acceleration of FDI inflow which was brought about by Deng Xiaoping's call for increased economic openness during his trip in early 1992. 
Besides FDI, ICT investment is also considered to have improved TFP growth via the reduction of transportation costs and transaction costs and increased efficiency. Meng and Li (2002) provide some evidence on the development of China's ICT sector. However, results for the TT and GI model are different regarding the ICT influence. The former found negative impact on TFP, while the latter found positive impact.

While the negative impact of ICT investment on TFP growth is ambiguous, the positive impact can be supported by existing researches. Gholami et al. (2005), in particular, found that ICT contributes to productivity and economic growth indirectly through attracting more FDI. Schreyer (2000) found that IT contributed significantly to productivity growth in the G-7 countries and Kraemer and Dedrick (2001) found growth in IT investment correlated with productivity growth.

While the effect of ICT investment on TFP growth in the GI model is significant, the magnitude is relatively low. This indicates that productivity growth could not be simply achieved as a result of increase in ICT investment, rather, it also requires the simultaneous changes in complementary factors like infrastructure, human capital and education that complement labor to make it more productive. See Dewan and Kraemer (1998). Therefore, our results imply that there is ample room for improvement in these complementary factors before increase in TFP growth from ICT investments could be realized. Also, Dewan and Kraemer (2000) mentioned that it could be due to learning effects so that developing countries must accumulate certain level of experience with information technologies before investment in this relatively new factor of production start to pay off. This explanation could be applied to our case of China, which is still in the developing state and has a relatively new ICT sector.

Besides the above factors, ROAD, PCNT and INV were found to have the correct signs in both models, implying that China's infrastructure, more educated workforce and total investment have all contributed positively to productivity growth in the past decade. Our results are consistent with those of Fleisher and Chen (1997), Mody and Wang (1997) and Demurger (2001), which found that infrastructure investment (roads, railways, waterways and telephones) has a statistically significant positive impact on growth. The results for PCNT and INV are expected, which indicate that both investment in capital and education 
attainment is essential and have immense potential in contributing to productivity growth in China.

\section{Summary and Conclusions}

The rapid economic growth in China during the past decade has attracted world-wide attention. Although capital accumulation has been considered as an important factor contributing to economic growth, continued increase in productivity is necessary to sustain growth and to reduce different forms of inequality in the society. In this paper, we examine the recent TFP growth of China by applying a panel data model on 30 Chinese provinces.

Given the rapid speed of development of the ICT sector in China during the 90s and the fact that previous studies of the economic impacts of ICT have been limited, this paper attempts to include ICT investment as one of the inputs of the production function, along with FDI and other traditional inputs such as capital and labour. To our knowledge, this is the first comparative analysis to explicitly include ICT investment as a factor of production along with traditional inputs for the case of China.

Similar to studies on other developing countries, the factor input elasticity measures of this paper implied that impacts of non-ICT capital investments are substantial, while those from ICT investment are not significant, indicating that for China, traditional inputs are still playing a more important role than non-traditional ICT investment in contributing to economic growth during the past decade.

One possible explanation for the insignificant impacts from ICT investment could be attributed to the overall lack of effective policy and ICT-enhancing complementary factors, such as human capital and infrastructure. It is widely believed that increasing level of ICT investment must be accompanied by corresponding investment in those complementary factors, so that amplifying effects of ICT investment could be obtained. In other words, positive and significant impact of ICT on production is not only the result of increase in ICT investment, but it also reflects simultaneous changes in education, infrastructure and other factors that complement labour and capital to make them more productive. Regulatory policies that promote more competition are crucial to develop the required infrastructure and foster an environment for higher level of ICT investment in a developing country like China. 
Besides, a deeper learning process for China in the ICT industry is also needed, so that it could accumulate a certain level of experience with information technologies before investments in this relatively new factor of production start to contribute more to the economic and productivity growth.

On top of traditional inputs of production and ICT investment, our results also provide some implications for impacts of FDI on production. Significant impact on production has been found for FDI, but the impact is relatively small. This could be attributed to high transaction costs imposed on the foreign-funded enterprises which limit the impact on GDP growth. Evidence has shown that the presence of ambiguity, complexity and inflexibility of policies are possible problems faced by the foreign investors and these will lead to high transaction costs. Besides, the lack of proper coordination among various bureaucratic units also creates conflicts between government bureaux and foreign investors, which hamper FDI's impact on production. A regional breakdown indicated that the eastern region is found to have the largest elasticities of FDI among the three regions, which implies that utilization and contribution of FDI is higher in the eastern region. For the western region, elasticity of capital is found to be largest among the three regions, while elasticity of FDI is the smallest, indicating the need of increasing investment in fixed assets to boost development in the region and to realize benefits for FDI and thereby narrowing the gap between the eastern region and western regions.

Besides investigation of the impacts of the above inputs on production, this paper also measures technical change and TFP. Technical progress was found over the whole sample period of 1993-2003 and the provinces are generally operating under increasing RTS. The increasing RTS might be attributed to a better reallocation of resources, skill upgrading and learning-by-doing. Regarding the results of TFP, at the national level, empirical results show positive TFP during the sample period, with relatively high average growth rate $(8.86 \%$ and 9.22\% in GI and TT models) found in early 1990s, i.e. 1991-1995, China's eighth 5-year plan. This is consistent with the fact that economic development is considered as most successful in the eighth 5-year period. But it then decreased after mid-90s.

A regional breakdown shows that the central region is found to have the highest average TFP growth while the western region is found to have the lowest average TFP growth during the sample period. This could be explained by the fact that the central region is 
having a more significant investment in infrastructure and labor endowment and enjoyed a fairly favourable investment environment and more preferential policies. While for the western region, more requirements for physical infrastructure construction are needed to increase the TFP growth.

While having the lowest average TFP, the western region is having the largest variation of production of provinces over time. The smallest variation of production occurred in the eastern region though. This could be supported by the fact that while the development of the eastern region is relatively more saturated in production over the past decade, the western region still enjoys an enormous development potential in various production areas. And this indirectly implies that more effort is required to put into the western region to reduce the regional gap.

ICT investment and FDI are found to have significant influence on the TFP growth, but the magnitude of influence is not very large. It is believed that ICT investment requires complementary factors, such as human capital and infrastructure to strengthen its influence on TFP growth. Since China is still in the progress of developing its ICT sector, our results indicate that there is still plenty of room for improvement before the gains from ICT investment to TFP growth can be realized. For FDI to have more influence on the TFP growth, the problems of ambiguity, complexity and inflexibility of policies should be eliminated first. 


\section{References}

Abramovitz, M., (1986). Catching Up, Forging Ahead and Falling Behind. Journal of Economic History 46, p.385-406.

Alfaro, L., (2003). Foreign Direct Investment and Growth: Does the Sector Matter? Harvard Business School, Boston.

Arayama, Y., Miyoshi, K., (2004). Regional Diversity and Sources of Economic Growth in China. The World Economy 27, p.1583-1607.

Baltagi, B.H., Griffin, J.M., (1988). A Generalized Error Component Model with Heteroscedastic Disturbances. International Economic Review 29, p.745-753.

Bao, S., Chang G.H., Sachs, J.D., Woo, W.T., (2002). Geographic Factors and China's Regional Developments under Market Reforms, 1979-1998. China Economic Review 13, p. 89-111.

Blomstrom, M., Lipsey, R., Zejan, M., (1994). What Explains the Growth of Developing Countries in William Baumol, Richard Nelson and Edward Wolff (eds.), Convergence and Productivity: Cross-National Studies and Historical Evidence, Oxford, Oxford University Press.

Borensztein, E., De Gregeorio, J., Lee, J. (1998). How does Foreign Direct Investment Affect Economic Growth? Journal of International Economics 45, p.115-135.

Borensztein, E., Ostry, D.J., (1996). Accounting for China's Growth Performance. American Economic Review 86, p.224- 228.

Cai, F., Dewen, W., Yang, D., (2001). Labor Market Distortions and Economic Growth: Examining Institutional Components of Regional Disparity in China. Working Paper no. 10, Center for Human Resource Studies, Chinese Academy of Social Sciences.

Chen, K., Wang, H.C., Zheng, Y.X., Jefferson G.H., Rawski, T.G., (1998). Productivity Change in Chinese Industry: 1953-1985. Journal of Comparative Economics 12, p.570591.

Chen, Y., (2001). Evidence of the Effect of Openness Policy on TFP and its Components: The Case of Chinese Provinces. Paper presented to the $3^{\text {rd }}$ International Conference on Chinese Economy "Has China become a Market Economy?" Clermont-Ferrant, France, May 2001.

Chow, G., (1993). Capital Formation and Economic Growth in China. Quarterly Journal of Economics 108, p.809- 842.

Christensen, L.R., Jorgenson, D.W., Lau, L.J. (1973). Transcendental Logarithmic Production Frontiers. Review of Economics and Statistics 55, 28-45.

Démurger, S., (2000). Economic Opening and Growth in China. OECD Development Centre Studies, Paris, March.

Démurger, S., (2001). Infrastructure Development and Economic Growth: An Explanation for Regional Disparities in China? Journal of Comparative economics 29, p.95-117.

Démurger, S., Sachs, J.D., Woo, W.T., Bao S., Chang, G., Mellinger, A., (2002). Geography, Economic Policy, and Regional Development in China. NBER Working Paper No. 8897.

Dewan, S., Kraemer, K.L., (1998). International Dimensions of the Productivity Paradox. Communications of the ACM 41, p.56-62.

Dewan, S., Kraemer, K.L., (2000). Information Technology and Productivity: Evidence from Country-Level Data. Management Science 46, p.548-562.

Dollar, D., (1992). Outward-oriented Developing Economies Really Do Grow More Rapidly: Evidence from 95 LDCs, 1976-1985. Economic Development and Cultural Change 40, p.523-544.

Ezaki, M., Sun, L., (1999). Growth Accounting in China for National, Regional, and Provincial Economies: 1981-1995. Asian Economic Journal 13, p. 39-71. 
Fleisher, B., Chen, J., (1997). The Coastal Non-Coastal Income Gap, Productivity, and Regional Economic Policy in China. Journal of Comparative Economics 25, p.220-236.

Gholami, R., Lee, S.Y., Heshmati, A., (2005). The Causal Relationship between ICT and FDI. Research Paper No. 2005/26, World Institute for World Economics Research.

Gipouloux, F., (1998). Integration or Disintegration? The Spatial Effects of Foreign Direct Investment in China. China Perspectives 17, pp. 6-13.

Gollop F., Frank, M., Jorgenson, D.W., (1980). U.S. Productivity Growth by Industry, 194773 in New Developments in Productivity Measurement and 60 Analysis, John W. Kendrick and Beatrice N. Vaccara (eds.), Chicago, University of Chicago Press.

Gollop, F., Roberts. M., (1983). Environmental Regulations and Productivity Growth: The Case of Fossil-Fueled Electric Power Generation. Journal of Political Economy 91, p.654- 674.

Görg, H. Greenaway, D., (2002). Much Ado About Nothing? Do Domestic Firms Really Benefit from Foreign Direct Investment? Research Paper 2001/37, Globalization and Labour Markets Programme, at Leverhulme Centre for Research on Globalization and Economic Policy, Nottingham.

Hanson, G.H., (2001). Should Countries Promote Foreign Direct Investment? G-24 Discussion Paper 9.

Heshmati, A., Nafar, N., (1998). A Production Analysis of the Manufacturing Industries in Iran, Technological Forecasting and Social Change 59, p.183-196.

Heshmati, A., Yang, W., (2005). Contribution of ICT to the Chinese Economic Growth, TEP Discussion Paper 2005:5, Seoul National University.

Holz, C., (2005). China's Reform Period Economic Growth: Why Angus Maddison Got It Wrong and What That Means. Development and Comp Systems 0504012, Economics Working Paper Archive at WUSTL.

Hu, A.G.Z., (2001). Ownership, Government R\&D, Private R\&D, and Productivity in Chinese Industry. Journal of Comparative Economics 29, p.136-157.

Hu, Z.L., Khan, M.S., (1997). Why is China Growing so Fast? IMF Staff Papers. Washington, DC: International Monetary Fund.

Jefferson, G.H., (1990). China's Iron and Steel Industry: Sources of Enterprise Efficiency and the Impact of Reform. Journal of Development Economics 33, p.329-355.

Jefferson, G.H., Rawski, T.G., Zheng, Y., (1992). Growth, Efficiency, and Convergence in China's State and Collective Industry. Economic Development and Cultural Change 40, p.239-266.

Jefferson, G.H., Xu, W., (1994). Assessing Gains in Efficient Production Among China's Industrial Enterprises. Economic Development and Cultural Change 42, p. 597-615.

Jefferson, G.H., Rawski, T.G., Zheng, Y., (1996). Chinese Industrial Productivity: Trends, Measurement Issues, and Recent Developments. Journal of Comparative Economics 23, p.146-180.

Jorgenson, D.W., Fraumeni, B.M, (1981). Relative Prices and Technical Change in Modeling and Measuring Natural Resource Substitution, E.R. Berndt and B.C. Fields (eds.), Cambridge, Mass.: MIT Press, p.17-47.

Kraemer, K L., Dedrick, J., (2001). Information Technology and Productivity: Results and Policy Implications of Cross-Country Studies in Information Technology, Productivity, and Economic Growth, M. Pohjola (ed.), Oxford: Oxford University Press.

Krugman, P. (1994). The Myth of Asia’s Miracle. Foreign Affairs 73, p. 62-78.

Kumbhakar, S.C., Heshmati, A., Hjalmarsson L., (1999). Parametric Approaches to Productivity Measurement: A Comparison among Alternative Models. Scandinavian Journal of Economics 101, p.405-424. 
Lee, J., (2000). Changes in the Sources of China's Regional Inequality. China Economic Review 3, p.232-245.

Lin, J.Y., (1992). Rural Reforms and Agricultural Growth in China. American Economic Review 82, p.34-51.

Maddison, A., (1998). Chinese Economic Performance in the Long Run. Paris: OECD.

Markusen, J., Venables, A., (1999). Foreign Direct Investment as a Catalyst for Industrial Development. European Economic Review 43, p.335-356.

Meng, Q., Li, M., (2002). New Economy and ICT Development in China. Information Economics and Policy 14, p.275-295.

Mody, A., Wang, F.Y., (1997). Explaining Industrial Growth in Coastal China: Economic Reforms... and What Else? World Bank Economic Review 11, p.293-325.

Ng, Y.C, Leung, C.M., (2002). Regional Economic Performance in China: A Panel Data Estimation. BRC Papers on China No. CP200204. Hong Kong Baptist University.

OCED, (1998). Open Market Matter: the Benefits of Trade and Investment Liberalisation. Paris: OCED.

Schreyer, P., (2000). The Contribution of Information and Communication Technology to Output Growth: A Study of the G7 Countries. STI Working Paper 2000/2 (Paris: OECD, 2000)

Sachs, J.D., Woo, W.T., (1997). Understanding China's Economic Performance, Harvard Institute of Economic Research Working Papers 1793, Harvard - Institute of Economic Research.

Solow, R.M., (1957). Technical Change and the Aggregate Production Function. The Review of Economics and Statistics 39, p.312-320.

Song, S., Chu, G.S.F., Chao, R, (2000). Inter-city Regional Disparity in China, China Economic Review11, 246-261.

Soto, M. (2000). Capital Flows and Growth in Developing Countries: Recent Empirical Evidence. OCED Development Centre Technical Paper No. 160. Paris: OCED.

Tinbergen, J. (1942). Critical Remarks on Some Business Cycle Theories. Econometrica 10, p. 129-146.

Wang, Y., Yao, Y., (2003). Sources of China's Economic Growth 1952-1999: Incorporating Human Capital Accumulation. China-Economic-Review 14, p.32-52.

Woo, W., (1998). Chinese Economic Growth: Sources and Prospects in the Chinese Economy, Michel Fouquin and Françoise Lemoine (eds.) (London: Economica).

World Bank, (1996). The Chinese Economy: Fighting Inflation, Deepening Reforms, Washington D.C..

Wu, Y., (1995). Productivity Growth, Technological Progress, and Technical Efficiency Change in China: A Three-Sector Analysis. Journal of Comparative Economics 21, p. 207-229.

Wu, Y., (1999). Productivity and Efficiency in China's Regional Economics in Economic Efficiency and Productivity Growth in the Asian-Pacific Region, Tsu-Tan Fu et al. (eds.), Edward Elgar.

Wu, Y., (2000). Productivity Growth and Economic Integration in the Southern China Region. Asain Economic Journal 14, p.39-54.

Wu, Y. (2004). China's Economic Growth: A Miracle with Chinese Characteristics. London: Routledge Curzon.

Xu, B., (2000). Multinational Enterprises, Technology diffusion, and Host Country Productivity Growth. Journal of Development Economics 62, p.477-493.

Xu, X., (1999). Agricultural Productivity in China. China Economic Review 10, p.108-121.

Xu, X., Wang, Y., (1999). Ownership Structure and Corporate Governance in Chinese Stock Companies. China Economic Review 10, p.75-98. 
Yeung, G., Mok, V., (2002). Government Policy and the Competitive Advantages of ForeignFinanced Firms in Guangdong Province of Southern China. Asian Business and Management 1, p.227-247.

Yusuf, S., (1994). China's Macroeconomic Performance and Management During Transition. The Journal of Economic Perspectives 8, p.71-92.

Zhang, X., Zhang, S., (2001). Impact of Ownership and Competition on the Productivity of Chinese Enterprises. Journal of Comparative Economics 29, p.327-346.

Zheng, J., Hu A., (2004). An Empirical Analysis of Provincial Productivity in China, 19792001. CCS Working Paper Series, Tsinghua University, No. 1, February 26.

Zheng, J., Liu, X. and Bigsten, A., (2003). Efficiency, Technical Progress, and Best Practice in Chinese State Enterprises (1980-1994). Journal of Comparative Economics 31, p.134152. 
Table 1

Summary Statistics of the Variables

\begin{tabular}{llrrrr}
\hline Variable Definition & Mean & S.D. & Minimum & Maximum \\
\hline year & & 1998 & 3.167 & 1993 & 2003 \\
east & & 0.367 & 0.483 & 0.000 & 1.000 \\
west & & 0.367 & 0.483 & 0.000 & 1.000 \\
ict & ict investment & $1,538.256$ & $1,483.798$ & 19.645 & $9,618.9715$ \\
lab & labor & $2,091.007$ & $1,529.419$ & 112.000 & $6,335.300$ \\
gdp & gross domestic product per capita & $2,743.910$ & $2,480.244$ & 37.280 & $13,625.870$ \\
cap & capital stock & $80,933.291$ & $81,340.483$ & $2,690.355$ & $536,026.786$ \\
inv & investment expenditure & $31,094.897$ & $29,557.019$ & 926.904 & $190,985.401$ \\
fdi & foreign direct investment inflow & $4871,194.5$ & $8,077,427.6$ & $2,809.0$ & $43,012,460.6$ \\
road & road infrastructure & $46,237.945$ & $30,312.832$ & $3,677.000$ & $183,341.000$ \\
tel & telephone lines & 3630381.3 & 3891388.7 & 22168.0 & 20595000.0 \\
gov & government expenditure & $11,764.896$ & $11,168.315$ & 283.249 & $84,104.732$ \\
trn & trend & 6.000 & 3.167 & 1.000 & 11.000 \\
pop & population in 10,000 & $4,110.346$ & $2,812.100$ & 232.000 & $11,830.400$ \\
pcnt & number of graduates of regular & & & & \\
open & institutions per 10,000 population & 9.214 & 8.323 & 2.294 & 56.872 \\
reform & ratio of SOE industrial value to & 0.282 & 0.342 & 0.040 & 2.054 \\
Abbreviation: SD=standard deviation. & & & & \\
Total number of observations: 330. & 51.113 & 19.296 & 9.414 & 89.029 \\
\hline
\end{tabular}


Table 2

Heteroscedastic GLS Translog Estimates with Time Trend and Time Dummy Model

\begin{tabular}{|c|c|c|c|c|c|}
\hline \multicolumn{3}{|c|}{ Time Trend (TT) } & \multicolumn{3}{|c|}{$\underline{\text { General Index (GI) }}$} \\
\hline Variable & Parameter Estimate & t Value & Variable & Parameter Estimate & t Value \\
\hline$\beta_{0}$ & -4.6436 & -3.80 & $\beta_{0}$ & -4.9282 & -4.49 \\
\hline$\beta_{l a b}$ & 0.9846 & 3.69 & $\beta_{l a b}$ & 0.6352 & 2.70 \\
\hline$\beta_{\text {cap }}$ & 0.8816 & 2.49 & $\beta_{\text {cap }}$ & 0.9104 & 2.93 \\
\hline$\beta_{i c t}$ & -0.2217 & -1.22 & $\beta_{\text {ict }}$ & -0.1264 & -0.79 \\
\hline$\beta_{f d i}$ & -0.1338 & -1.12 & $\beta_{f d i}$ & 0.0104 & 0.10 \\
\hline$\beta_{t r n}$ & 0.2695 & 5.68 & $\beta_{\text {lab } 2}$ & -0.0154 & -0.39 \\
\hline$\beta_{l a b 2}$ & -0.0088 & -0.20 & $\beta_{\text {cap } 2}$ & 0.2399 & 3.85 \\
\hline$\beta_{\text {cap } 2}$ & 0.2040 & 2.89 & $\beta_{\text {ict } 2}$ & 0.0457 & 1.58 \\
\hline$\beta_{\text {ict } 2}$ & 0.0598 & 1.85 & $\beta_{f d i 2}$ & 0.0412 & 4.10 \\
\hline$\beta_{f d i 2}$ & 0.0517 & 4.54 & $\beta_{\text {labcap }}$ & -0.1408 & -5.70 \\
\hline$\beta_{t r n 2}$ & -0.0159 & -8.08 & $\beta_{\text {labict }}$ & 0.0575 & 2.94 \\
\hline$\beta_{\text {labcap }}$ & -0.1357 & -4.81 & $\beta_{\text {labfdi }}$ & 0.0644 & 4.26 \\
\hline$\beta_{\text {labict }}$ & 0.0239 & 1.09 & $\beta_{\text {labtrn }}$ & -0.0041 & -1.05 \\
\hline$\beta_{\text {labfdi }}$ & 0.0581 & 3.37 & $\beta_{\text {capict }}$ & -0.0695 & -2.36 \\
\hline$\beta_{\text {labtrn }}$ & 0.0062 & 1.46 & $\beta_{\text {capfdi }}$ & -0.0902 & -3.93 \\
\hline$\beta_{\text {capict }}$ & -0.0464 & -1.40 & $\beta_{\text {captrn }}$ & -0.0027 & -0.41 \\
\hline$\beta_{\text {capfdi }}$ & -0.0874 & -3.34 & $\beta_{i c t f d i}$ & -0.0008 & -0.07 \\
\hline$\beta_{\text {captrn }}$ & 0.0087 & 1.17 & $\beta_{\text {icttrn }}$ & 0.0004 & 0.06 \\
\hline$\beta_{\text {ictfdi }}$ & 0.0008 & 0.06 & $\beta_{\text {fditrn }}$ & 0.0045 & 1.52 \\
\hline$\beta_{\text {icttrn }}$ & -0.0273 & -3.63 & $\beta_{t 2}$ & 0.2579 & 5.52 \\
\hline \multirow[t]{9}{*}{$\beta_{\text {fditrn }}$} & 0.0061 & 1.84 & $\beta_{t 3}$ & 0.4537 & 5.16 \\
\hline & & & $\beta_{t 4}$ & 0.5893 & 4.43 \\
\hline & & & $\beta_{t 5}$ & 0.6327 & 3.56 \\
\hline & & & $\beta_{t 6}$ & 0.6608 & 2.93 \\
\hline & & & $\beta_{t 7}$ & 0.6543 & 2.38 \\
\hline & & & $\beta_{t 8}$ & 0.7052 & 2.17 \\
\hline & & & $\beta_{t 9}$ & 0.7344 & 1.95 \\
\hline & & & $\beta_{t 10}$ & 0.7750 & 1.82 \\
\hline & & & $\beta_{t 11}$ & 0.8595 & 1.81 \\
\hline Adjusted & & 0.9994 & Adjusted $\mathrm{R}^{2}$ & & 0.9995 \\
\hline
\end{tabular}

Notes:

${ }^{1}$ Total number of observations $=330$.

${ }^{2} \beta_{\mathrm{t}} \mathrm{s}$ are the year dummies. 
Table 3

Variance Components and Transformation Parameters

\begin{tabular}{|c|c|c|c|c|c|}
\hline \multirow{2}{*}{\multicolumn{2}{|c|}{ Eastern Region }} & $\alpha_{\mathrm{i}}$ & $\sigma_{\mathrm{vi}}^{2}$ & $\sigma_{u}{ }^{2}$ & $\overline{\sigma_{e i}{ }^{2}}$ \\
\hline & & & & & \\
\hline \multicolumn{2}{|c|}{ Beijing } & 0.3212 & 0.0004 & 0.0039 & 0.0085 \\
\hline \multicolumn{2}{|l|}{ Tianjin } & 0.4735 & 0.0009 & 0.0039 & 0.0141 \\
\hline \multicolumn{2}{|l|}{ Hebei } & 0.4565 & 0.0008 & 0.0039 & 0.0132 \\
\hline \multicolumn{2}{|c|}{ Liaoning } & 0.4919 & 0.0010 & 0.0039 & 0.0151 \\
\hline \multicolumn{2}{|c|}{ Shandong } & 0.4599 & 0.0009 & 0.0039 & 0.0134 \\
\hline \multicolumn{2}{|c|}{ Shanghai } & 0.4615 & 0.0009 & 0.0039 & 0.0135 \\
\hline \multicolumn{2}{|l|}{ Zhejiang } & 0.4753 & 0.0009 & 0.0039 & 0.0142 \\
\hline \multicolumn{2}{|l|}{ Jiangsu } & 0.5643 & 0.0015 & 0.0039 & 0.0206 \\
\hline \multicolumn{2}{|c|}{ Fujian } & 0.6125 & 0.0020 & 0.0039 & 0.0260 \\
\hline \multicolumn{2}{|c|}{ Guangdong } & 0.3860 & 0.0006 & 0.0039 & 0.0104 \\
\hline \multicolumn{2}{|c|}{ Hainan } & 0.0000 & 0.0000 & 0.0039 & 0.0039 \\
\hline \multicolumn{2}{|l|}{ Guangxi } & 0.4440 & 0.0008 & 0.0039 & 0.0126 \\
\hline \multicolumn{6}{|c|}{ Central Region } \\
\hline \multicolumn{2}{|c|}{ Shanxi } & 0.0666 & 0.0001 & 0.0039 & 0.0045 \\
\hline \multicolumn{2}{|c|}{ Inner Mongolia } & 0.0000 & 0.0000 & 0.0039 & 0.0039 \\
\hline \multicolumn{2}{|c|}{ Jilin } & 0.7261 & 0.0044 & 0.0039 & 0.0520 \\
\hline \multicolumn{2}{|c|}{ Heilongjiang } & 0.5618 & 0.0015 & 0.0039 & 0.0203 \\
\hline \multicolumn{2}{|c|}{ Anhui } & 0.5293 & 0.0012 & 0.0039 & 0.0176 \\
\hline \multicolumn{2}{|l|}{ Jiangxi } & 0.2641 & 0.0003 & 0.0039 & 0.0072 \\
\hline \multicolumn{2}{|l|}{ Henan } & 0.8360 & 0.0128 & 0.0039 & 0.1451 \\
\hline \multicolumn{2}{|l|}{ Hunan } & 0.6445 & 0.0025 & 0.0039 & 0.0309 \\
\hline \multicolumn{2}{|l|}{ Hubei } & 0.4034 & 0.0006 & 0.0039 & 0.0110 \\
\hline \multicolumn{6}{|c|}{ Western Region } \\
\hline \multicolumn{2}{|c|}{ Sichuan } & 0.7233 & 0.0043 & 0.0039 & 0.0510 \\
\hline Yunnan & & 0.6359 & 0.0023 & 0.0039 & 0.0295 \\
\hline Guizhou & & 0.6192 & 0.0021 & 0.0039 & 0.0269 \\
\hline Shaanxi & & 0.8315 & 0.0121 & 0.0039 & 0.1375 \\
\hline Gansu & & 0.8408 & 0.0137 & 0.0039 & 0.1541 \\
\hline Qinghai & & 0.6183 & 0.0021 & 0.0039 & 0.0268 \\
\hline Ningxia & & 0.7726 & 0.0065 & 0.0039 & 0.0755 \\
\hline Tibet & & 0.6095 & 0.0020 & 0.0039 & 0.0256 \\
\hline Xinjiang & & 0.7988 & 0.0084 & 0.0039 & 0.0965 \\
\hline National & Mean & 0.5209 & 0.0029 & 0.0039 & 0.0360 \\
\hline & S.D. & 0.2273 & 0.0039 & 0.0000 & 0.0426 \\
\hline Eastern & Mean & 0.4289 & 0.0009 & 0.0039 & 0.0138 \\
\hline & S.D. & 0.1539 & 0.0005 & 0.0000 & 0.0055 \\
\hline Central & Mean & 0.4480 & 0.0026 & 0.0039 & 0.0325 \\
\hline & S.D. & 0.2890 & 0.0041 & 0.0000 & 0.0449 \\
\hline Western & Mean & 0.7167 & 0.0059 & 0.0039 & 0.0693 \\
\hline & S.D. & 0.0973 & 0.0045 & 0.0000 & 0.0501 \\
\hline
\end{tabular}

Note:

${ }^{1}$ The national and regional figures were obtained by averaging the provincial estimates. 
Table 4A

Elasticities, RTS and Technical Change by Province and Over Time, Time Trend model

\begin{tabular}{|c|c|c|c|c|c|c|c|c|c|c|c|}
\hline & $E_{L}$ & $E_{\text {cap }}$ & $E_{i c t}$ & $E_{f d i}$ & RTS1 & $E_{t}$ & Puretrn1 & Nonntrn1 & $\mathrm{TC}$ & TFP1 & Solow1 \\
\hline \multicolumn{12}{|l|}{ Eastern Region } \\
\hline Beijing & 0.563 & 0.521 & -0.028 & 0.067 & 1.124 & 7.44 & 17.42 & -9.97 & 7.45 & 8.15 & 9.60 \\
\hline Tianjin & 0.627 & 0.500 & -0.074 & 0.096 & 1.149 & 9.64 & 17.42 & -7.78 & 9.64 & 10.52 & 11.67 \\
\hline Hebei & 0.517 & 0.356 & -0.009 & 0.136 & 1.000 & 9.07 & 17.42 & -8.35 & 9.07 & 9.15 & 10.63 \\
\hline Liaoning & 0.564 & 0.266 & 0.009 & 0.188 & 1.027 & 8.86 & 17.42 & -8.56 & 8.86 & 9.00 & 10.03 \\
\hline Shandong & 0.573 & 0.438 & -0.027 & 0.095 & 1.079 & 8.48 & 17.42 & -8.94 & 8.48 & 8.67 & 10.96 \\
\hline Shanghai & 0.535 & 0.279 & -0.008 & 0.181 & 0.987 & 9.87 & 17.42 & -7.55 & 9.87 & 9.96 & 7.05 \\
\hline Zhejiang & 0.661 & 0.196 & 0.003 & 0.209 & 1.069 & 9.37 & 17.42 & -8.05 & 9.37 & 9.43 & 9.05 \\
\hline Jiangsu & 0.663 & 0.108 & 0.055 & 0.255 & 1.081 & 7.73 & 17.42 & -9.69 & 7.73 & 8.36 & 9.65 \\
\hline Fujian & 0.514 & 0.494 & -0.032 & 0.063 & 1.039 & 8.52 & 17.42 & -8.90 & 8.52 & 8.73 & 7.62 \\
\hline Guangdong & 0.516 & 0.298 & 0.012 & 0.151 & 0.977 & 8.75 & 17.42 & -8.67 & 8.75 & 8.63 & 10.96 \\
\hline Hainan & 0.628 & 0.185 & 0.036 & 0.202 & 1.052 & 8.06 & 17.42 & -9.36 & 8.06 & 8.28 & 9.54 \\
\hline Guangxi & 0.588 & 0.286 & 0.019 & 0.161 & 1.054 & 7.94 & 17.42 & -9.48 & 7.94 & 8.17 & 9.77 \\
\hline \multicolumn{12}{|l|}{ Central Region } \\
\hline Shanxi & 0.546 & 0.394 & -0.011 & 0.122 & 1.051 & 8.41 & 17.42 & -9.01 & 8.41 & 8.70 & 8.27 \\
\hline Inner Mongolia & 0.504 & 0.599 & -0.060 & 0.045 & 1.088 & 8.60 & 17.42 & -8.82 & 8.60 & 9.09 & 10.21 \\
\hline Jilin & 0.568 & 0.308 & 0.010 & 0.157 & 1.042 & 8.29 & 17.42 & -9.13 & 8.29 & 8.61 & 9.94 \\
\hline Heilongjiang & 0.706 & 0.183 & 0.002 & 0.231 & 1.121 & 9.18 & 17.42 & -8.24 & 9.18 & 10.39 & 9.13 \\
\hline Anhui & 0.729 & 0.398 & -0.065 & 0.139 & 1.200 & 9.71 & 17.42 & -7.71 & 9.71 & 10.36 & 9.00 \\
\hline Jiangxi & 0.501 & 0.568 & -0.042 & 0.025 & 1.052 & 8.18 & 17.42 & -9.23 & 8.19 & 8.38 & 10.81 \\
\hline Henan & 0.562 & 0.399 & 0.003 & 0.103 & 1.068 & 7.52 & 17.42 & -9.90 & 7.52 & 7.74 & 11.04 \\
\hline Hunan & 0.617 & 0.291 & -0.005 & 0.165 & 1.068 & 8.90 & 17.42 & -8.52 & 8.90 & 9.47 & 6.96 \\
\hline Hubei & 0.591 & 0.254 & 0.014 & 0.173 & 1.031 & 8.61 & 17.42 & -8.81 & 8.61 & 8.75 & 9.51 \\
\hline
\end{tabular}




\begin{tabular}{|c|c|c|c|c|c|c|c|c|c|c|c|c|}
\hline \multicolumn{13}{|c|}{ Western Region } \\
\hline Sichuan & & 0.546 & 0.221 & 0.036 & 0.182 & 0.985 & 8.26 & 17.42 & -9.16 & 8.26 & 8.30 & 15.14 \\
\hline Yunnan & & 0.550 & 0.374 & 0.005 & 0.105 & 1.034 & 7.87 & 17.42 & -9.55 & 7.87 & 8.12 & 7.23 \\
\hline Guizhou & & 0.574 & 0.363 & 0.003 & 0.107 & 1.047 & 7.96 & 17.42 & -9.46 & 7.96 & 8.19 & 7.65 \\
\hline Shaanxi & & 0.541 & 0.418 & -0.019 & 0.102 & 1.042 & 8.59 & 17.42 & -8.83 & 8.59 & 8.76 & 9.40 \\
\hline Gansu & & 0.495 & 0.553 & -0.031 & 0.026 & 1.043 & 7.86 & 17.42 & -9.56 & 7.86 & 8.02 & 8.96 \\
\hline Qinghai & & 0.560 & 0.715 & -0.100 & -0.043 & 1.133 & 8.85 & 17.42 & -8.57 & 8.85 & 9.68 & -2.62 \\
\hline Ningxia & & 0.533 & 0.735 & -0.097 & -0.049 & 1.123 & 8.63 & 17.42 & -8.79 & 8.63 & 9.17 & 6.60 \\
\hline Tibet & & 0.684 & 0.630 & -0.089 & 0.002 & 1.227 & 8.36 & 17.42 & -9.06 & 8.36 & 9.41 & 10.11 \\
\hline Xinjiang & & 0.469 & 0.678 & -0.048 & -0.037 & 1.062 & 7.33 & 17.42 & -10.09 & 7.33 & 7.54 & 11.85 \\
\hline \multirow[t]{2}{*}{ Overall } & Mean & 0.574 & 0.400 & -0.018 & 0.112 & 1.069 & 8.49 & 17.42 & -8.92 & 8.50 & 8.86 & 9.19 \\
\hline & S.D. & 0.065 & 0.168 & 0.040 & 0.081 & 0.058 & 0.66 & 0.00 & 0.66 & 0.66 & 0.78 & 2.83 \\
\hline \multirow[t]{2}{*}{ Eastern } & Mean & 0.579 & 0.327 & -0.004 & 0.150 & 1.053 & 8.64 & 17.42 & -8.78 & 8.65 & 8.92 & 9.71 \\
\hline & S.D. & 0.055 & 0.136 & 0.034 & 0.061 & 0.052 & 0.76 & 0.00 & 0.76 & 0.76 & 0.74 & 1.34 \\
\hline \multirow[t]{2}{*}{ Central } & Mean & 0.592 & 0.377 & -0.017 & 0.129 & 1.080 & 8.60 & 17.42 & -8.82 & 8.60 & 9.05 & 9.43 \\
\hline & S.D. & 0.081 & 0.138 & 0.030 & 0.064 & 0.052 & 0.63 & 0.00 & 0.63 & 0.63 & 0.88 & 1.28 \\
\hline \multirow[t]{6}{*}{ Western } & Mean & 0.550 & 0.521 & -0.038 & 0.044 & 1.077 & 8.19 & 17.42 & -9.23 & 8.19 & 8.58 & 8.26 \\
\hline & S.D. & 0.060 & 0.183 & 0.049 & 0.083 & 0.072 & 0.48 & 0.00 & 0.48 & 0.48 & 0.72 & 4.85 \\
\hline & year & $E_{L}$ & $E_{\text {cap }}$ & $E_{i c t}$ & $E_{f d i}$ & RTS1 & $E_{t}$ & Puretrn1 & Nonntrn1 & TC & TFP1 & Solow1 \\
\hline & 1993 & 0.561 & 0.347 & 0.067 & 0.107 & 1.083 & 19.12 & 25.36 & -6.23 & 19.13 & 19.12 & 0.00 \\
\hline & 1994 & 0.572 & 0.339 & 0.076 & 0.107 & 1.094 & 15.82 & 23.77 & -7.95 & 15.82 & 16.57 & 28.49 \\
\hline & 1995 & 0.580 & 0.343 & 0.045 & 0.117 & 1.085 & 14.46 & 22.18 & -7.72 & 14.46 & 14.88 & 20.88 \\
\hline
\end{tabular}




\begin{tabular}{|c|c|c|c|c|c|c|c|c|c|c|c|}
\hline 1996 & 0.582 & 0.355 & 0.027 & 0.117 & 1.081 & 12.41 & 20.60 & -8.19 & 12.41 & 13.03 & 14.46 \\
\hline 1997 & 0.588 & 0.362 & 0.003 & 0.124 & 1.077 & 10.65 & 19.01 & -8.35 & 10.66 & 11.18 & 5.92 \\
\hline 1998 & 0.588 & 0.380 & -0.008 & 0.119 & 1.079 & 8.14 & 17.42 & -9.28 & 8.14 & 8.14 & 2.92 \\
\hline 1999 & 0.576 & 0.413 & -0.024 & 0.108 & 1.082 & 5.78 & 15.83 & -10.05 & 5.78 & 6.07 & 2.12 \\
\hline 2000 & 0.567 & 0.443 & -0.050 & 0.101 & 1.061 & 3.98 & 14.24 & -10.26 & 3.98 & 4.23 & 8.29 \\
\hline 2001 & 0.575 & 0.445 & -0.068 & 0.108 & 1.061 & 1.93 & 12.66 & -10.73 & 1.93 & 2.33 & 1.24 \\
\hline 2002 & 0.569 & 0.472 & -0.116 & 0.114 & 1.039 & 1.29 & 11.07 & -9.77 & 1.30 & 1.80 & 4.78 \\
\hline 2003 & 0.558 & 0.505 & -0.149 & 0.109 & 1.022 & -0.13 & 9.48 & -9.61 & -0.13 & 0.08 & 11.99 \\
\hline
\end{tabular}

Table 4B

Elasticities, RTS and Technical Change by Province and Over Time, Time Dummy Model

\begin{tabular}{|c|c|c|c|c|c|c|c|c|c|c|c|}
\hline & $E_{L}$ & $E_{\text {cap }}$ & $E_{i c t}$ & $E_{f d i}$ & RTS2 & $E_{t}$ & Puretrn2 & Nonntrn2 & $\mathrm{TC}$ & TFP2 & Solow2 \\
\hline \multicolumn{12}{|c|}{ Eastern Region } \\
\hline Beijing & 0.566 & 0.544 & -0.021 & 0.024 & 1.114 & 9.50 & 7.81 & 1.68 & 9.49 & 10.05 & 9.17 \\
\hline Tianjin & 0.596 & 0.527 & -0.048 & 0.056 & 1.131 & 9.73 & 7.81 & 1.91 & 9.72 & 10.26 & 11.20 \\
\hline Hebei & 0.491 & 0.378 & 0.062 & 0.112 & 1.043 & 8.54 & 7.81 & 0.72 & 8.53 & 8.91 & 10.10 \\
\hline Liaoning & 0.570 & 0.286 & 0.057 & 0.142 & 1.055 & 9.21 & 7.81 & 1.40 & 9.21 & 9.51 & 9.18 \\
\hline Shandong & 0.531 & 0.449 & 0.040 & 0.080 & 1.100 & 8.68 & 7.81 & 0.87 & 8.68 & 9.10 & 9.68 \\
\hline Shanghai & 0.514 & 0.304 & 0.065 & 0.148 & 1.032 & 8.76 & 7.81 & 0.94 & 8.75 & 9.29 & 6.42 \\
\hline Zhejiang & 0.611 & 0.186 & 0.112 & 0.197 & 1.107 & 8.68 & 7.81 & 0.87 & 8.68 & 8.99 & 7.53 \\
\hline Jiangsu & 0.687 & 0.101 & 0.109 & 0.205 & 1.102 & 9.54 & 7.81 & 1.73 & 9.54 & 10.33 & 8.20 \\
\hline Fujian & 0.464 & 0.510 & 0.043 & 0.057 & 1.073 & 8.25 & 7.81 & 0.43 & 8.24 & 8.70 & 7.91 \\
\hline Guangdong & 0.481 & 0.308 & 0.109 & 0.139 & 1.037 & 8.10 & 7.81 & 0.28 & 8.09 & 8.32 & 10.32 \\
\hline Hainan & 0.600 & 0.172 & 0.136 & 0.188 & 1.096 & 8.54 & 7.81 & 0.72 & 8.53 & 9.01 & 8.89 \\
\hline Guangxi & 0.571 & 0.287 & 0.092 & 0.138 & 1.087 & 8.72 & 7.81 & 0.91 & 8.72 & 9.14 & 8.82 \\
\hline
\end{tabular}


Central Region

\begin{tabular}{|c|c|c|c|c|c|c|c|c|c|c|c|}
\hline Shanxi & 0.535 & 0.414 & 0.034 & 0.088 & 1.073 & 8.99 & 7.81 & 1.17 & 8.98 & 9.33 & 8.13 \\
\hline Inner Mongolia & 0.509 & 0.648 & -0.072 & -0.009 & 1.076 & 9.63 & 7.81 & 1.82 & 9.63 & 9.98 & 9.18 \\
\hline Jilin & 0.556 & 0.318 & 0.072 & 0.127 & 1.073 & 8.85 & 7.81 & 1.04 & 8.85 & 9.46 & 9.28 \\
\hline Heilongjiang & 0.688 & 0.178 & 0.072 & 0.194 & 1.131 & 9.55 & 7.81 & 1.74 & 9.55 & 11.08 & 7.30 \\
\hline Anhui & 0.675 & 0.399 & -0.007 & 0.113 & 1.180 & 9.71 & 7.81 & 1.89 & 9.70 & 10.24 & 7.86 \\
\hline Jiangxi & 0.443 & 0.585 & 0.029 & 0.024 & 1.082 & 8.13 & 7.81 & 0.32 & 8.13 & 8.55 & 10.17 \\
\hline Henan & 0.534 & 0.402 & 0.071 & 0.089 & 1.096 & 8.53 & 7.81 & 0.72 & 8.53 & 8.85 & 10.65 \\
\hline Hunan & 0.577 & 0.291 & 0.082 & 0.148 & 1.099 & 8.72 & 7.81 & 0.91 & 8.72 & 9.65 & 7.51 \\
\hline Hubei & 0.550 & 0.250 & 0.117 & 0.163 & 1.079 & 8.34 & 7.81 & 0.53 & 8.34 & 8.83 & 8.38 \\
\hline \multicolumn{12}{|l|}{ Western Region } \\
\hline Sichuan & 0.518 & 0.220 & 0.140 & 0.170 & 1.048 & 8.11 & 7.81 & 0.30 & 8.11 & 8.47 & 14.59 \\
\hline Yunnan & 0.495 & 0.370 & 0.109 & 0.110 & 1.083 & 7.92 & 7.81 & 0.11 & 7.92 & 8.55 & 6.77 \\
\hline Guizhou & 0.505 & 0.351 & 0.121 & 0.121 & 1.098 & 7.78 & 7.81 & -0.03 & 7.78 & 8.53 & 6.92 \\
\hline Shaanxi & 0.501 & 0.431 & 0.055 & 0.088 & 1.075 & 8.47 & 7.81 & 0.65 & 8.46 & 8.84 & 8.88 \\
\hline Gansu & 0.438 & 0.566 & 0.045 & 0.029 & 1.079 & 7.98 & 7.81 & 0.17 & 7.98 & 8.48 & 8.42 \\
\hline Qinghai & 0.447 & 0.724 & -0.009 & -0.018 & 1.144 & 7.98 & 7.81 & 0.16 & 7.97 & 9.18 & 1.63 \\
\hline Ningxia & 0.436 & 0.752 & -0.024 & -0.034 & 1.131 & 8.12 & 7.81 & 0.31 & 8.12 & 8.79 & 7.36 \\
\hline Tibet & 0.578 & 0.618 & -0.005 & 0.020 & 1.212 & 8.63 & 7.81 & 0.82 & 8.63 & 9.88 & 10.00 \\
\hline Xinjiang & 0.403 & 0.694 & 0.020 & -0.026 & 1.091 & 7.82 & 7.81 & 0.01 & 7.82 & 8.24 & 10.61 \\
\hline \multirow[t]{2}{*}{ Overall } & 0.536 & 0.409 & 0.054 & 0.096 & 1.094 & 8.65 & 7.81 & 0.84 & 8.65 & 9.22 & 8.70 \\
\hline & 0.073 & 0.176 & 0.056 & 0.070 & 0.039 & 0.60 & 0.00 & 0.60 & 0.60 & 0.70 & 2.11 \\
\hline Eastern & 0.557 & 0.338 & 0.063 & 0.124 & 1.081 & 8.85 & 7.81 & 1.04 & 8.85 & 9.30 & 8.95 \\
\hline
\end{tabular}




\begin{tabular}{|c|c|c|c|c|c|c|c|c|c|c|c|}
\hline & 0.064 & 0.146 & 0.055 & 0.059 & 0.033 & 0.52 & 0.00 & 0.52 & 0.52 & 0.63 & 1.31 \\
\hline \multirow[t]{2}{*}{ Central } & 0.563 & 0.387 & 0.044 & 0.104 & 1.099 & 8.94 & 7.81 & 1.13 & 8.94 & 9.55 & 8.72 \\
\hline & 0.077 & 0.152 & 0.056 & 0.065 & 0.036 & 0.58 & 0.00 & 0.58 & 0.58 & 0.80 & 1.17 \\
\hline \multirow[t]{2}{*}{ Western } & 0.480 & 0.525 & 0.050 & 0.051 & 1.107 & 8.09 & 7.81 & 0.28 & 8.09 & 8.77 & 8.35 \\
\hline & 0.054 & 0.189 & 0.061 & 0.074 & 0.049 & 0.29 & 0.00 & 0.29 & 0.29 & 0.50 & 3.50 \\
\hline year & $E_{L}$ & $E_{c a p}$ & $E_{i c t}$ & $E_{f d i}$ & RTS2 & $E_{t}$ & Puretrn2 & Nonntrn2 & TC & TFP2 & Solow2 \\
\hline 1993 & 0.540 & 0.426 & 0.021 & 0.101 & 1.088 & 0.91 & 0.00 & 0.91 & 0.91 & 0.91 & 0.00 \\
\hline 1994 & 0.560 & 0.394 & 0.050 & 0.100 & 1.103 & 26.64 & 25.79 & 0.85 & 26.64 & 27.12 & 28.53 \\
\hline 1995 & 0.555 & 0.388 & 0.048 & 0.108 & 1.100 & 20.45 & 19.58 & 0.87 & 20.45 & 20.89 & 21.93 \\
\hline 1996 & 0.553 & 0.386 & 0.054 & 0.107 & 1.100 & 14.41 & 13.56 & 0.85 & 14.41 & 15.19 & 13.88 \\
\hline 1997 & 0.553 & 0.381 & 0.054 & 0.110 & 1.098 & 5.24 & 4.35 & 0.89 & 5.24 & 6.06 & 6.04 \\
\hline 1998 & 0.555 & 0.384 & 0.062 & 0.102 & 1.103 & 3.70 & 2.81 & 0.90 & 3.71 & 4.28 & 1.66 \\
\hline 1999 & 0.541 & 0.403 & 0.067 & 0.090 & 1.101 & 0.16 & -0.65 & 0.81 & 0.16 & 0.92 & -0.21 \\
\hline 2000 & 0.523 & 0.424 & 0.065 & 0.083 & 1.095 & 5.84 & 5.09 & 0.75 & 5.84 & 6.29 & 6.68 \\
\hline 2001 & 0.530 & 0.412 & 0.070 & 0.085 & 1.097 & 3.72 & 2.92 & 0.80 & 3.72 & 4.62 & 2.04 \\
\hline 2002 & 0.504 & 0.437 & 0.052 & 0.088 & 1.081 & 4.89 & 4.06 & 0.82 & 4.88 & 5.51 & 4.51 \\
\hline 2003 & 0.480 & 0.463 & 0.045 & 0.083 & 1.071 & 9.20 & 8.45 & 0.75 & 9.20 & 9.61 & 10.66 \\
\hline
\end{tabular}

Notes:

${ }^{1} \mathrm{E}$ indicates input elasticity.

${ }^{2} \mathrm{RTS}$ indicates returns to scale.

${ }^{3}$ Puretrn indicates the pure technical change while nonntrn indicates the non-neutral technical change.

${ }^{4} \mathrm{TC}$ indicates total technical change.

${ }^{5}$ TFP indicates total factor productivity. 
Table 5

Determinants of TFP Growth by Time Trend Based and Time Dummy Model, NT=330.

\begin{tabular}{|c|c|c|c|c|c|c|c|c|}
\hline \multicolumn{3}{|c|}{ TT Model } & \multicolumn{6}{|c|}{ GI Model } \\
\hline Variable & $\begin{array}{r}\text { Parameter } \\
\text { Estimate }\end{array}$ & t Value & Variable & $\begin{array}{r}\text { Parameter } \\
\text { Estimate }\end{array}$ & t Value & Variable & $\begin{array}{r}\text { Parameter } \\
\text { Estimate } \\
\end{array}$ & t Value \\
\hline$\beta_{0}$ & 27.0273 & 32.27 & $\beta_{0}$ & -24.1658 & -3.41 & $\alpha_{17}$ & -0.1452 & -0.12 \\
\hline$\beta_{\text {ict }}$ & -2.4782 & -21.51 & $\beta_{\text {ict }}$ & 0.4567 & 2.88 & $\alpha_{18}$ & 0.5890 & 0.48 \\
\hline$\beta_{i n v}$ & 0.5379 & 3.30 & $\beta_{i n v}$ & 0.6172 & 1.56 & $\alpha_{19}$ & -1.3093 & -1.06 \\
\hline$\beta_{f d i}$ & 0.7915 & 16.33 & $\beta_{f d i}$ & 0.9785 & 8.45 & $\alpha_{20}$ & -1.2969 & -1.16 \\
\hline$\beta_{\text {road }}$ & 0.0216 & 0.26 & $\beta_{\text {roa }}$ & 0.6165 & 1.63 & $\alpha_{21}$ & -0.6341 & -0.52 \\
\hline$\beta_{\text {tel }}$ & -0.0114 & -0.10 & $\beta_{\text {tel }}$ & -0.2600 & -0.91 & $\alpha_{22}$ & -1.6363 & -1.19 \\
\hline$\beta_{\text {gov }}$ & 0.1702 & 1.15 & $\beta_{\text {gov }}$ & -0.3295 & -1.06 & $\alpha_{23}$ & 2.4272 & 1.67 \\
\hline$\beta_{p c n t}$ & 0.0015 & 0.18 & $\beta_{p c n t}$ & 0.0055 & 0.20 & $\alpha_{24}$ & 0.9884 & 0.69 \\
\hline$\beta_{\text {open }}$ & -0.1726 & -2.60 & $\beta_{\text {open }}$ & -0.3148 & -1.53 & $\alpha_{25}$ & 6.0083 & 2.72 \\
\hline$\beta_{\text {reform }}$ & -0.0026 & -0.70 & $\beta_{\text {reform }}$ & -0.0113 & -1.80 & $\alpha_{26}$ & 0.2348 & 0.21 \\
\hline$\beta_{t 2}$ & -0.9704 & -5.25 & $\alpha_{2}$ & 1.5273 & 1.87 & $\alpha_{27}$ & 1.5117 & 1.13 \\
\hline$\beta_{t 3}$ & -2.9463 & -15.31 & $\alpha_{3}$ & -1.6741 & -1.45 & $\alpha_{28}$ & 5.8917 & 3.10 \\
\hline$\beta_{t 4}$ & -4.4311 & -21.29 & $\alpha_{4}$ & -1.0261 & -1.10 & $\alpha_{29}$ & 5.2697 & 3.09 \\
\hline$\beta_{t 5}$ & -6.1918 & -28.30 & $\alpha_{5}$ & -0.5225 & -0.78 & $\alpha_{30}$ & 2.6072 & 2.00 \\
\hline$\beta_{t 6}$ & -8.4262 & -37.32 & $\alpha_{6}$ & -2.5951 & -2.55 & $\beta_{t 2}$ & 26.2116 & 100.92 \\
\hline$\beta_{t 7}$ & -9.6683 & -42.09 & $\alpha_{7}$ & -1.3032 & -1.25 & $\beta_{t 3}$ & 19.9434 & 58.51 \\
\hline$\beta_{t 8}$ & -11.2877 & -47.96 & $\alpha_{8}$ & 0.2734 & 0.24 & $\beta_{t 4}$ & 14.0952 & 34.34 \\
\hline$\beta_{t 9}$ & -12.8426 & -51.53 & $\alpha_{9}$ & -1.9625 & -1.70 & $\beta_{t 5}$ & 4.7142 & 9.57 \\
\hline$\beta_{t 10}$ & -14.2861 & -60.12 & $\alpha_{10}$ & -2.5567 & -1.99 & $\beta_{t 6}$ & 2.7245 & 4.83 \\
\hline \multirow[t]{6}{*}{$\beta_{t 11}$} & -16.1697 & -66.26 & $\alpha_{11}$ & 0.2582 & 0.20 & $\beta_{t 7}$ & -0.3723 & -0.60 \\
\hline & & & $\alpha_{12}$ & 2.0904 & 1.34 & $\beta_{t 8}$ & 5.0661 & 7.32 \\
\hline & & & $\alpha_{13}$ & 0.9706 & 0.80 & $\beta_{t 9}$ & 3.0389 & 3.65 \\
\hline & & & $\alpha_{14}$ & 1.3190 & 0.98 & $\beta_{t 10}$ & 3.8402 & 4.21 \\
\hline & & & $\alpha_{15}$ & 0.9264 & 0.88 & $\beta_{t 11}$ & 7.9767 & 7.69 \\
\hline & & & $\alpha_{16}$ & 0.2135 & 0.19 & & & \\
\hline
\end{tabular}




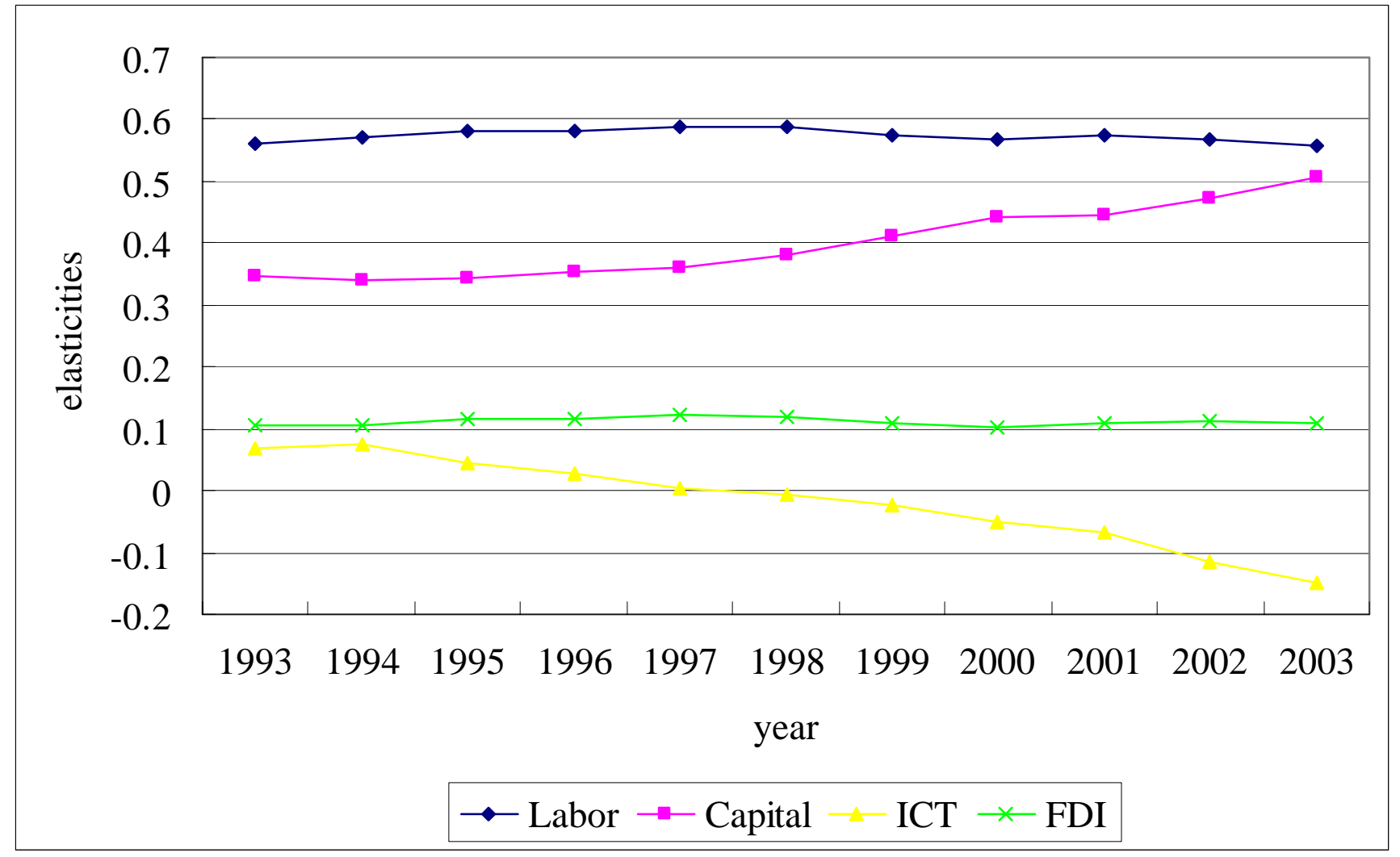

Figure 1. Development of Input Elasticities over time by TT Model

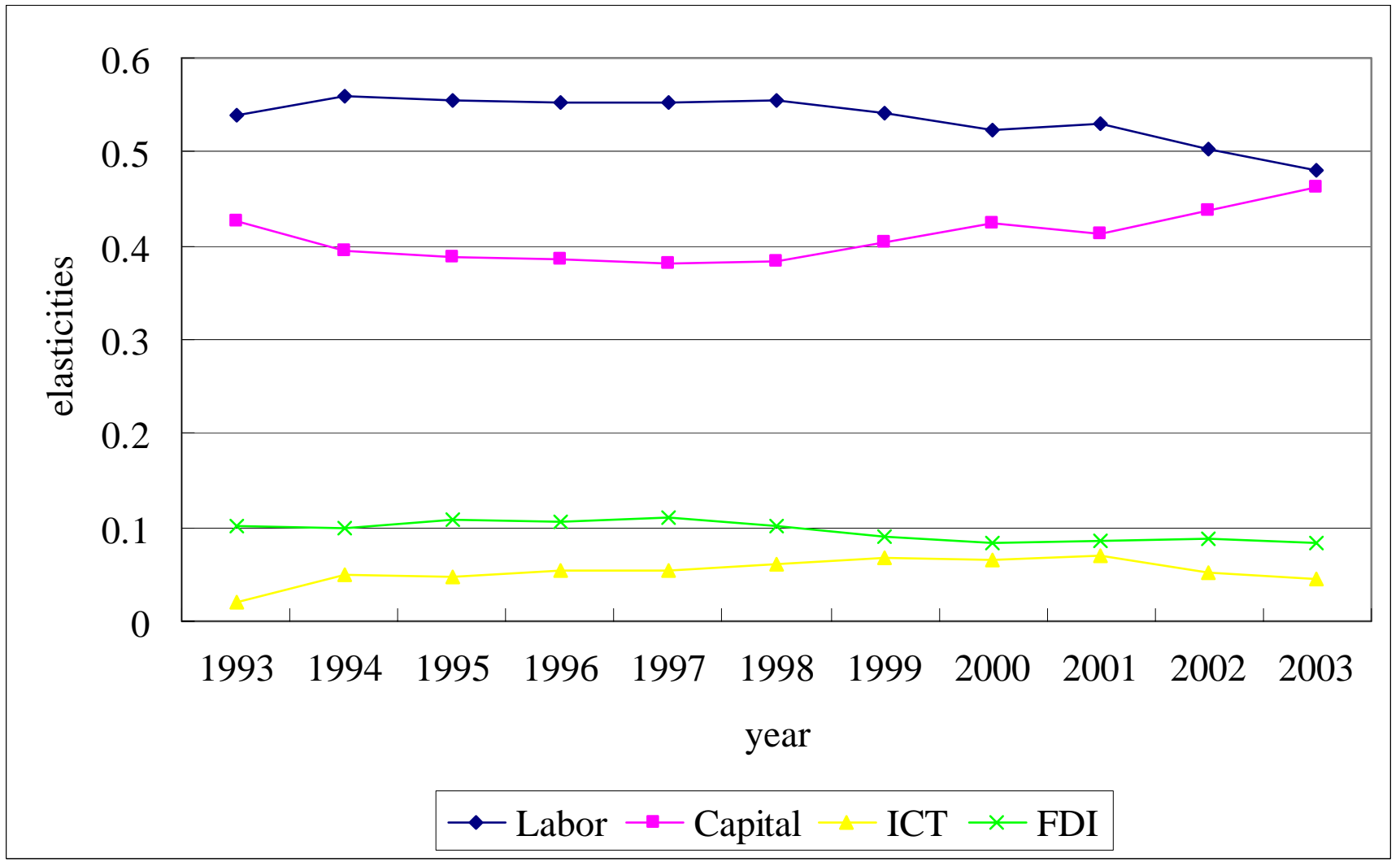

Figure 2. Development of Input Elasticities over time by GI Model 


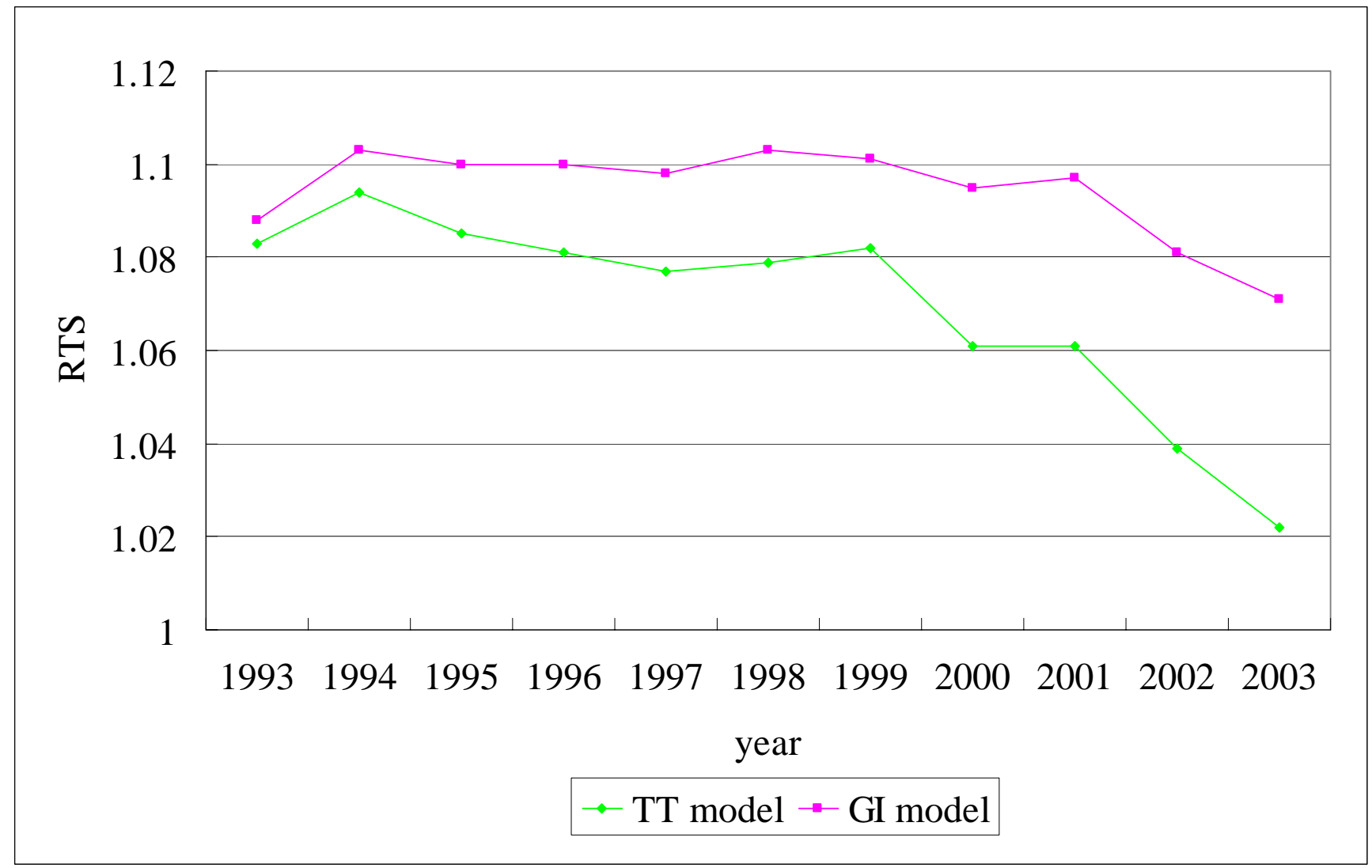

Figure 3. Development of RTS over time by TT Model and GI Model

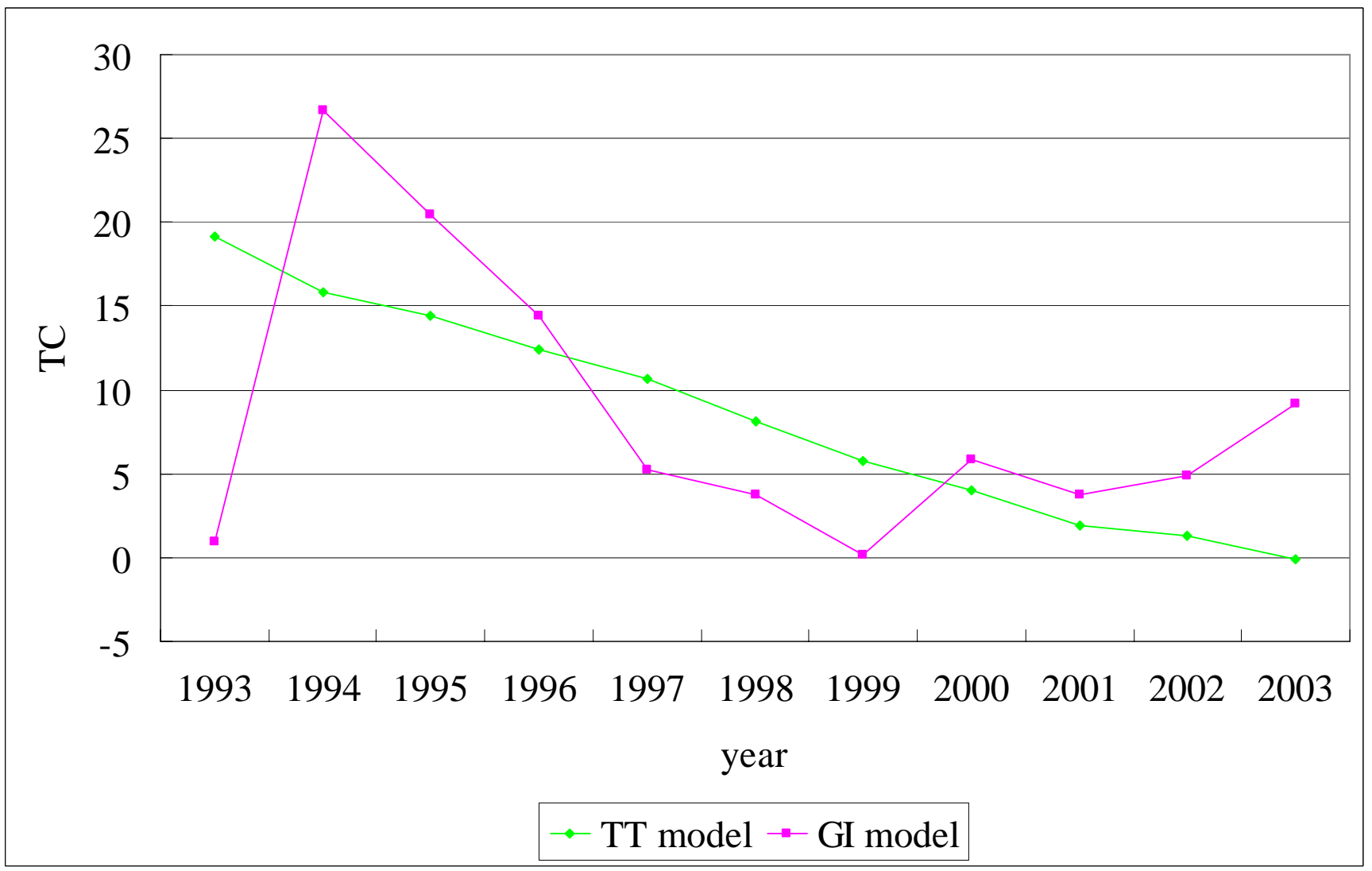

Figure 4. Development of Rate of Technical Change over time by TT Model and GI Model 


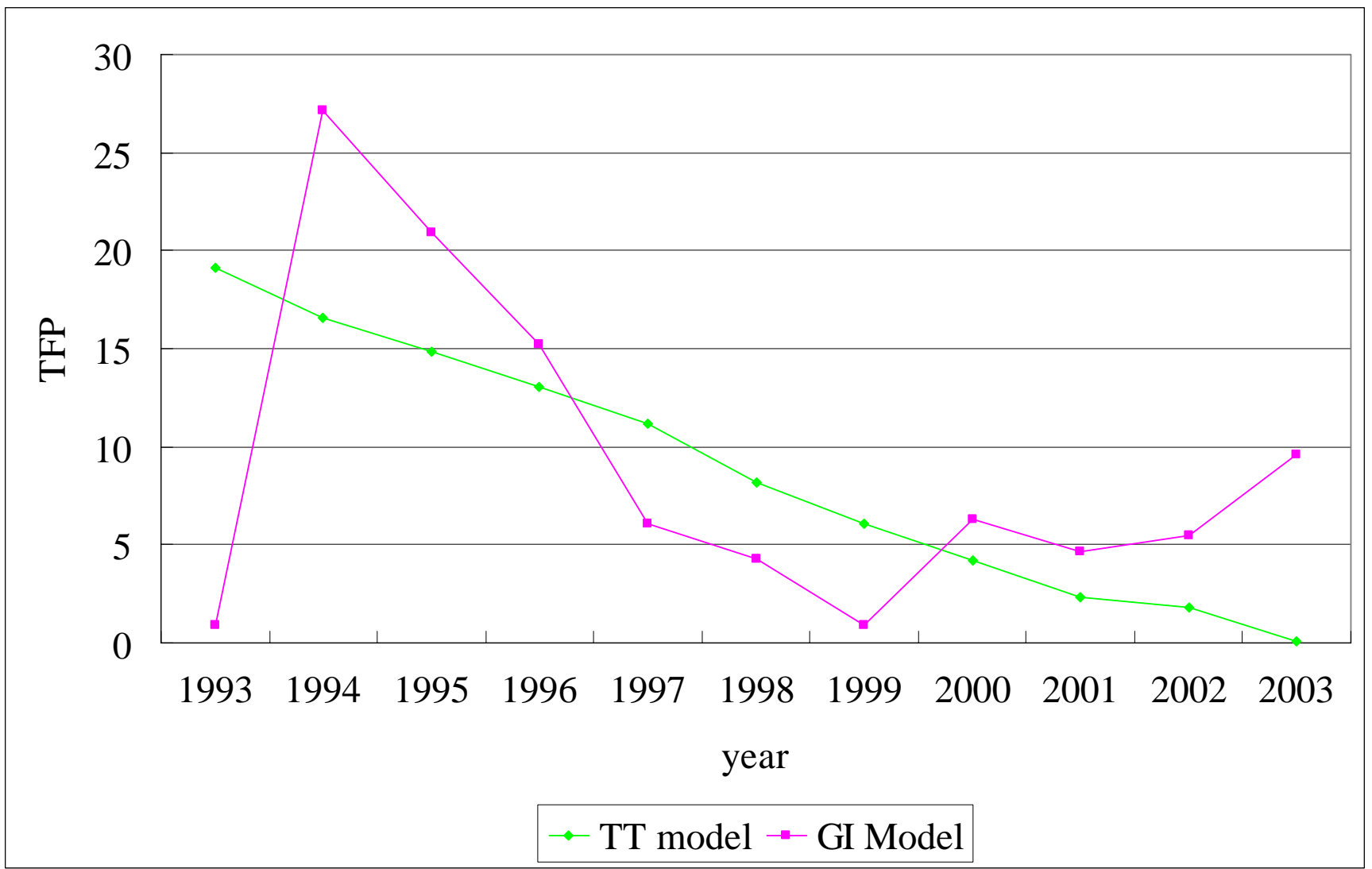

Figure 5. Development of TFP Growth over time by TT Model and GI Model 